د · · جوخة الحارثي

\title{
المقطوعة الغزلية:
}

\section{أصولها، ارتباطها بالغتاء، تطورها}

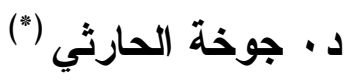

المقدمة :

تهذف هذه الدراسة إلى نقديم تحليل لمصطلح "الكقطوعة الغزلية": نشأته،

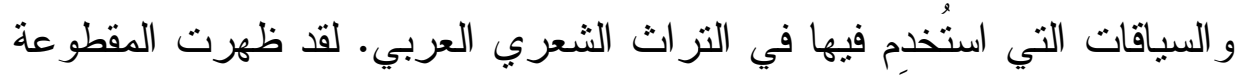
الغزلية منذ العصر الجاهلي، ولكن تبلورها على شكل فن مستقل له خصائصها الفنية نم تدريجيا عبر العصور الإسلامية، وتتعرض هذه الدراسة إلى الى الآراء

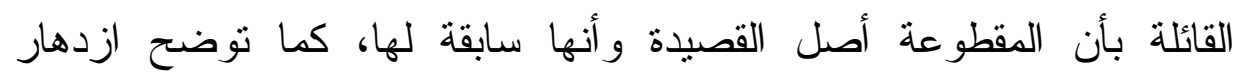

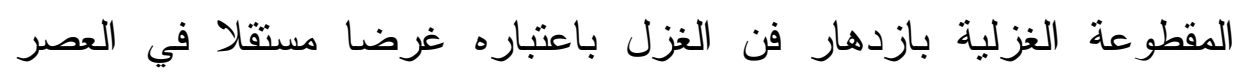

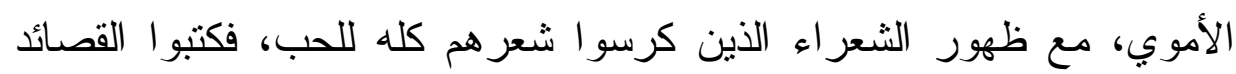

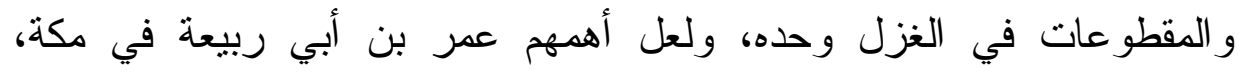
و الثعر اء العذريون في البادية من أمثال جميل بثنية وقيس لبنى. كما نتافتش

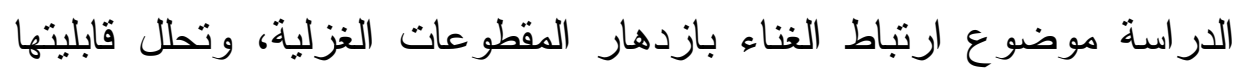

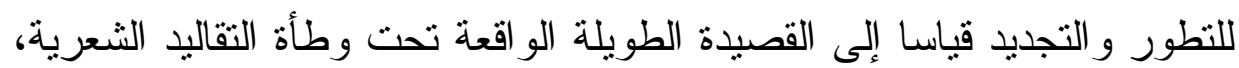

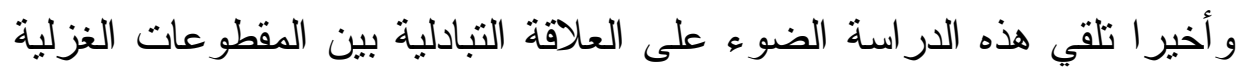

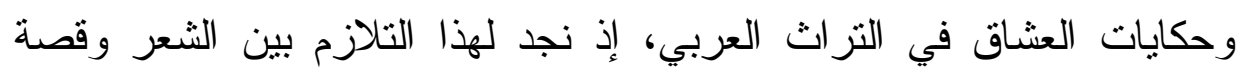

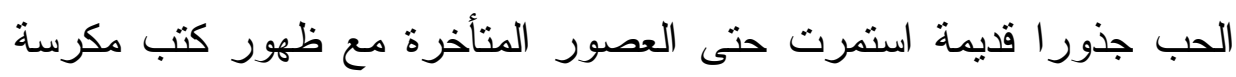
لأخبار العشاق.

كلمات مفتاحية: المقطوعة الغزلية، أصول الثشعر، الغناء، قصص العشاق،

$$
\text { عمر بن أبي ربيعة، العذريون. }
$$




\section{هل المقطوعة أصل القصيدة؟}

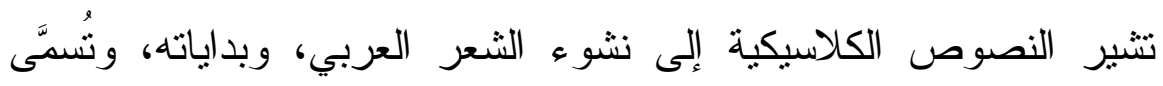

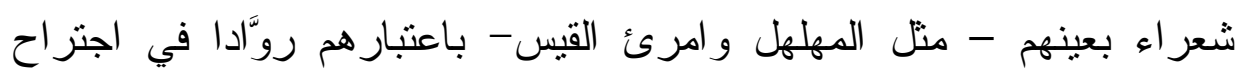
القصيدة العربية المتكاملة، الني أسست لتقاليد القصيدة القديمة؛ يقول ابن سلام الفئ

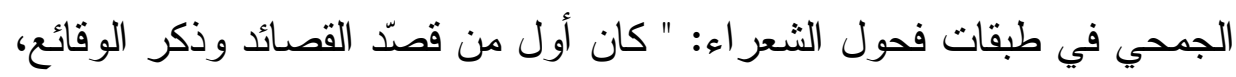

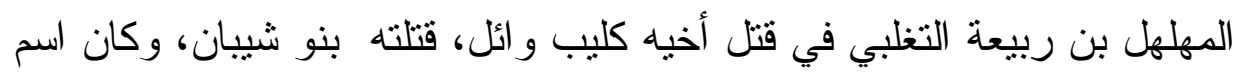

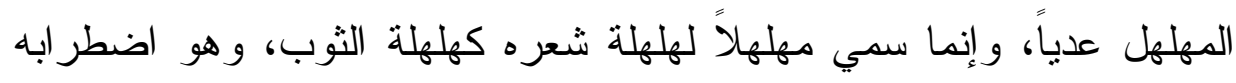
و اختلافه"(")، وهكذا رأي الجاحظ حيث قال: "و الثعر حديث الميلاد، صغير

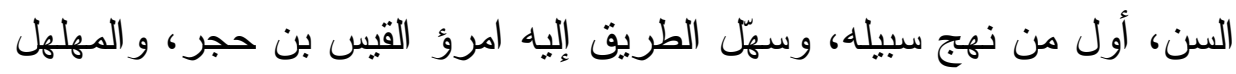

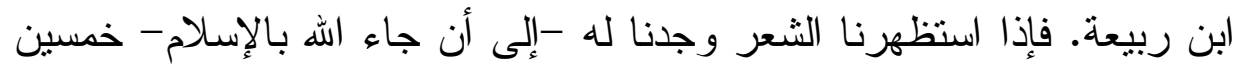

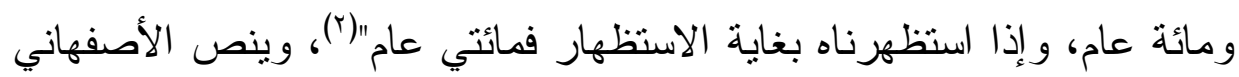

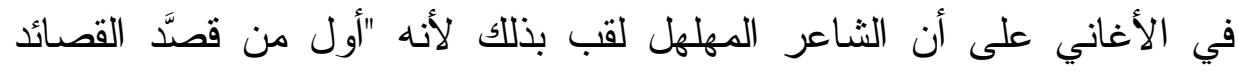

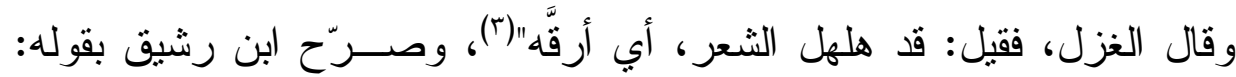

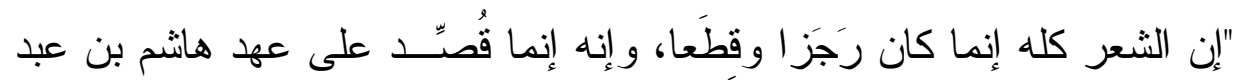

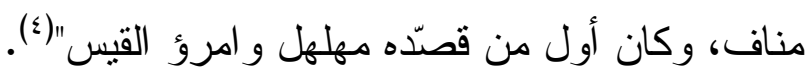

(1) ابن سلام، طبقات فحول الثعراء، ت: محمود محمد شاكر، جا (القاهرة: مطبعة

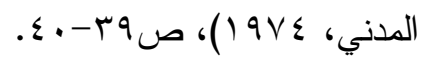

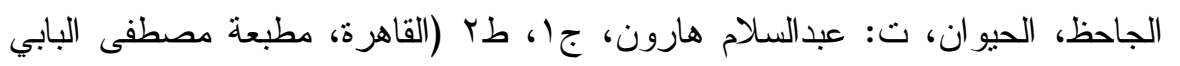

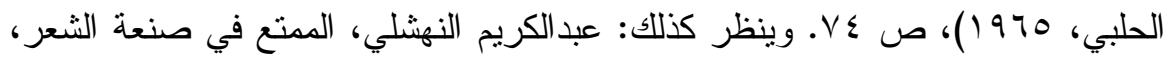

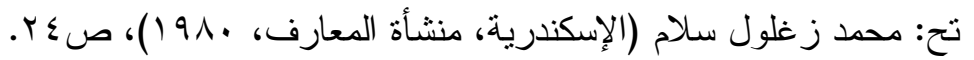

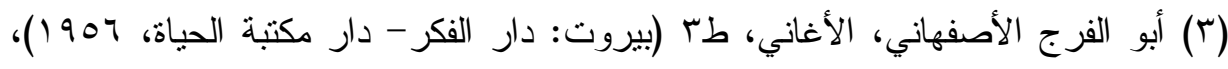
$.0 \mathrm{Vlo}$

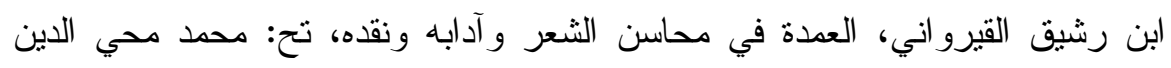

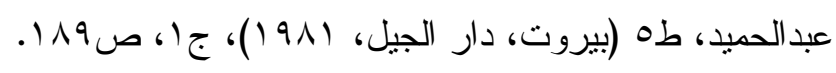




\section{د · جوخة الحارثي}

نرى في هذه النصوص اتفاق النقاد القدامى على دور المهلهل في هلهلة الشعر، على أن ابن رشيق يصرِّح بأن الثعر من قبل المهلهل كان قطعا ورجزا، و اعتبار المهاكل أول من قصنَّ القصائد يثير ضمنا إلى أن الثعر قبله لم يكن قصائد بل مقطوعات، ونجد شيخو يقبل هذا الر أب، ويقرٌ بأن المهلهل هو أول من قال القصائد الطو ال وتغزَّل (') على أن مارجليوث يتشكك في هذا الر أي، ويرى بأن المقصود بالقصيدة الطويلة غير واضح، فهل المقصود هو ما

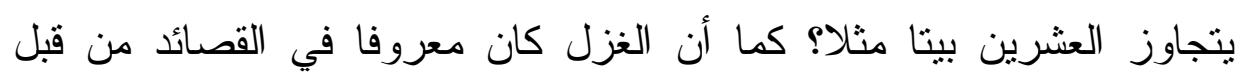
المهلهل، بالإضافة إلى الرأي القائل بأن امرئ القيس بن حجر وليس المهاهل هو أول من قال القصائد(؟). ويرى عبدالله الطيب في "المرشد إلى فهم أثعار العرب وصناعتها": "أن النظم بدأ مرسلا قائها على جرس الحركات و السكنات، ثم تطوّر إلى سجع يعني بجرس المقاطع، ومنه نشأت فكرة التسميط القائمة على تعدد القو افي مع الميل إلى إحكام الوزن شيئا فثنيئا حتى نشأ الرجز، ومن ثم نشأت أوزان الثعر الأخرى"(ז). ورأي الطيب في نشوء الثعر يذكر السجع ومن ثم الرجز ولكنه لا يشير صر احة إلى المقطوعات، في حين يبدو أن الأمر قد استقر عند الباحثين من بعد على أن الشعر بدأ بالسجع فالرجز فالمقطوعات

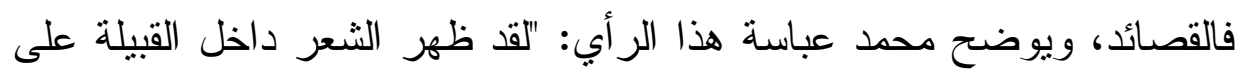
شكل مقطوعات قصيرة، واستمر ذلك إلى غاية نهاية القرن الخامس الميلادي، حيث انتقل الثعر في بداية القرن السادس الميلادي من اللهجات المحلية في جنوب الجزيرة إلى اللغة الفصحى العامة ومن المقطوعة إلى القصيدة، إلا أن

Pere Cheikho in Margoliouth, The Origins of Arabic Poetry,

on $r$ Novmber, $r .14$, p. $\{r$ l.wWw.cambridge.orglcore

Margoliouth, p. \&rr.

(r) عبداله الطيب، المرشد إلى فهم أثنعار العرب وصناعتها، ط؛ (الخرطوم، دار جامعة

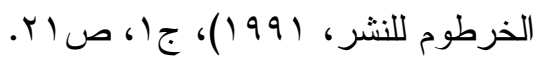


الثعر العربي لم يعرف القافية في بداية الأمر، بل جاء مسجوعا قبل أن ينتقل

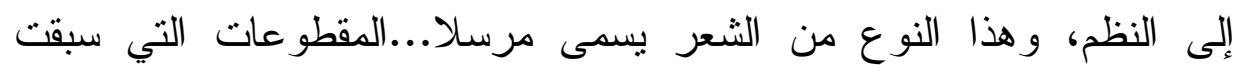

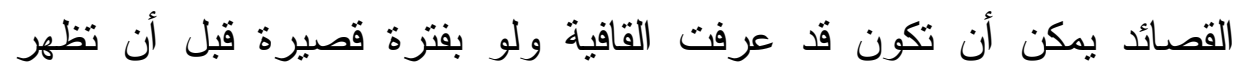
القصيدة في القرن السادس الميلادي" (1). ولكن هل يمكننا اعتماد المقطوعات الواردة في شعر الجاهليين ومختار ات اتلات

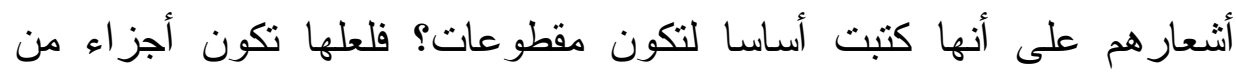

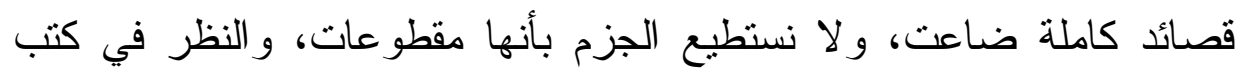

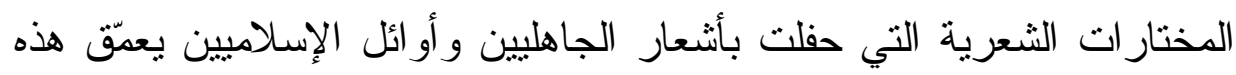

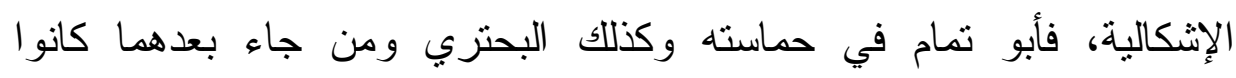

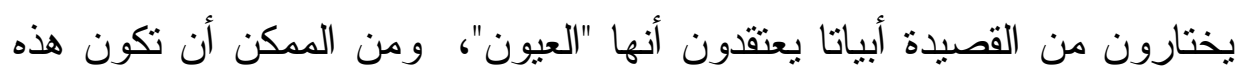

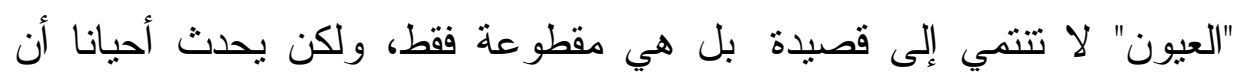

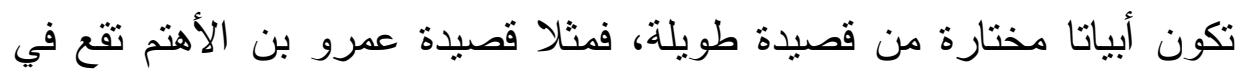

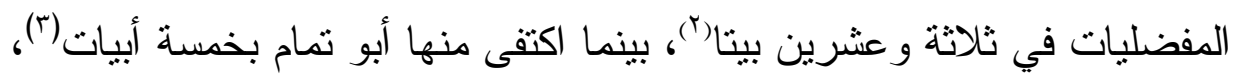

$$
\text { فمدار الاختيار عند أبي تمام الجودة والاستحسان. }
$$

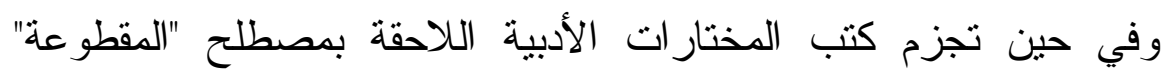

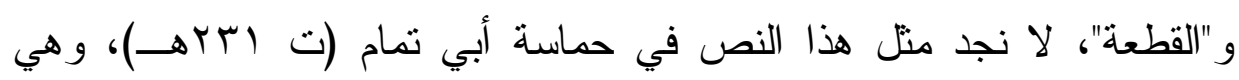

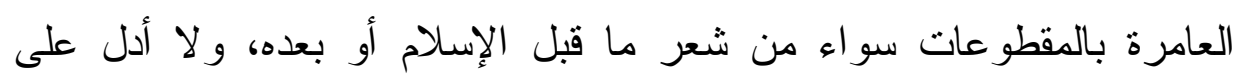

(1) محمد عباسة، اللهجات في الأزجال و الموشحات الأندلسية، إنسانيات: المجلة الجزائرية

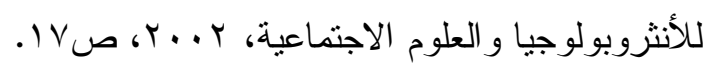

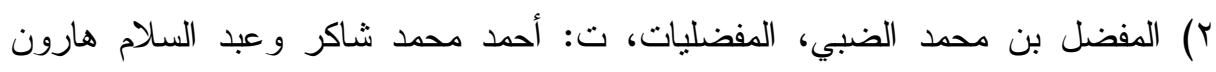

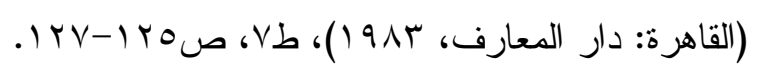

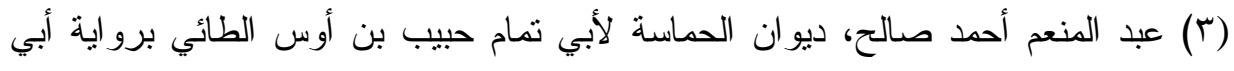

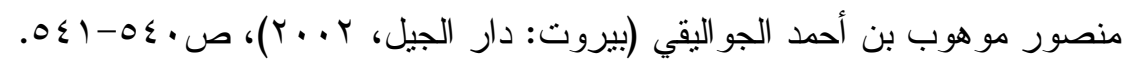




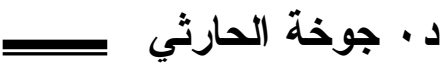

أهميتها من كثرة شروحها حتى عرف من شر احها ما يقارب العشرين(') . وإن دان

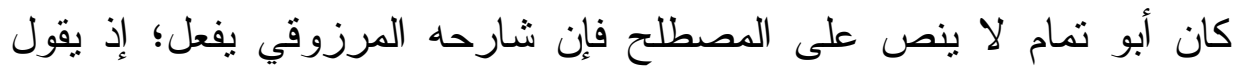
معلقا على مقطوعة الربيع بن زياد العبسي في رثاء ماللك بن زهير العبسي:

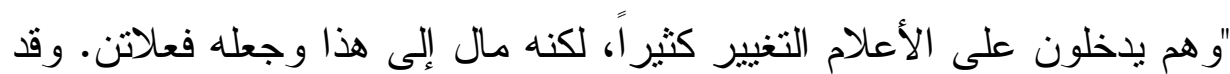

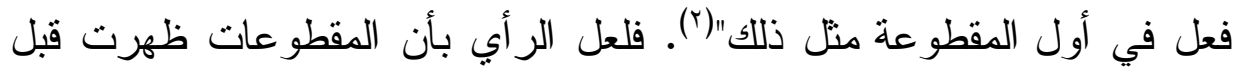

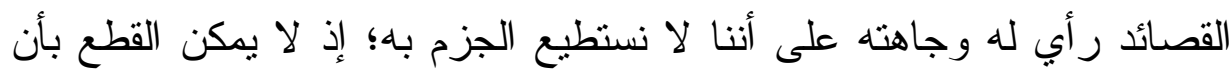
المقطو عات الجاهلية أسبق من القصائد و لا حنى بأنها ليست أجز اء من قصائد.

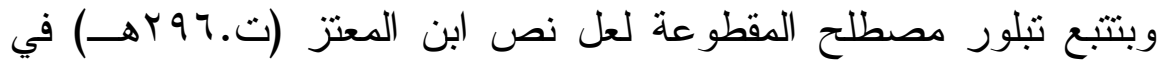

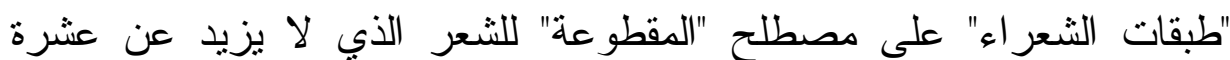

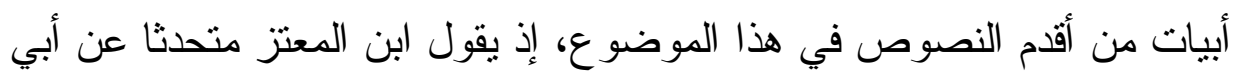

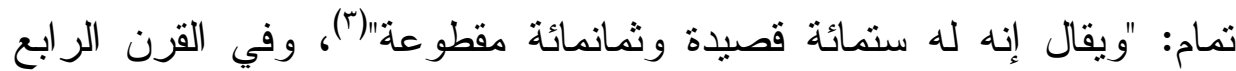
الهجري وصف القاضي التتوخي (ت. rیrهــ) بيتين للشاعر البيغاء في

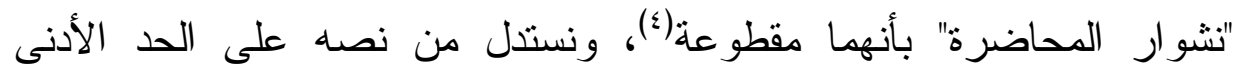

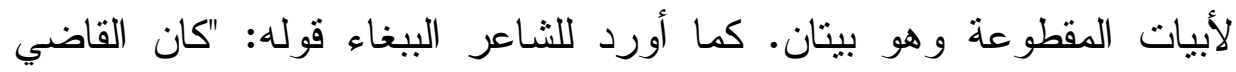

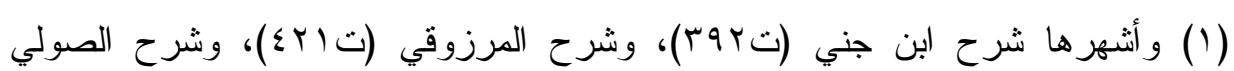

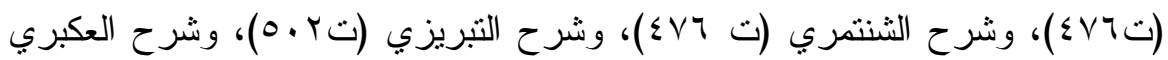

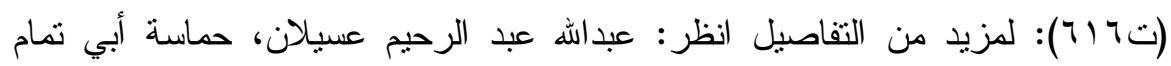

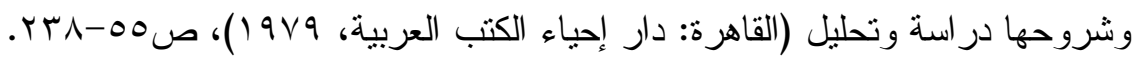

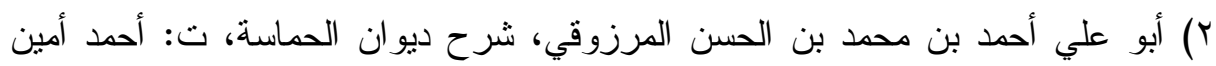

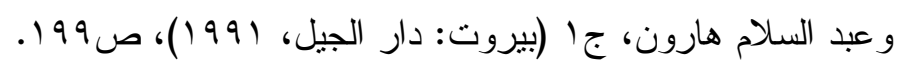

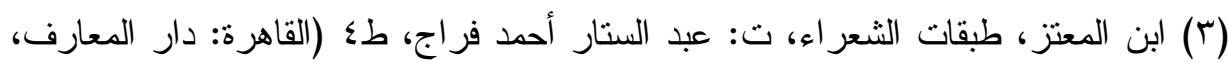

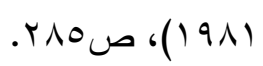

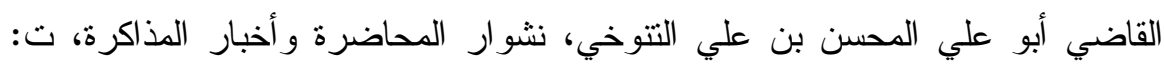

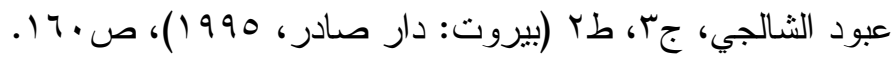


أبو القاسم التتوخي أنثدنا جميع شعره أو أكثره، و لا أعلم هذه القطعة فيما أنثدنا هل هي له أم لا"()، وأورد مقطو عة أو قطعة - كما أسماها- من ثلاثة

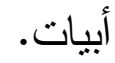

وفي القرن الخامس يقول الثعالبي (ت 9rوءهـ) في "يتيمة الدهر" عن أبي

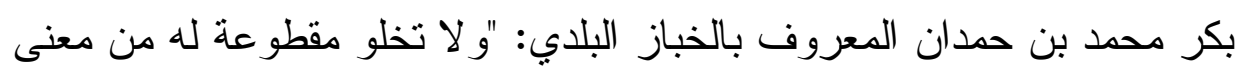

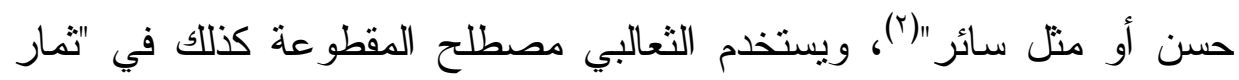
القلوب في المضاف و المنسوب" في حديثه عن الثناعر أبي غلالة المخزومي ولئي

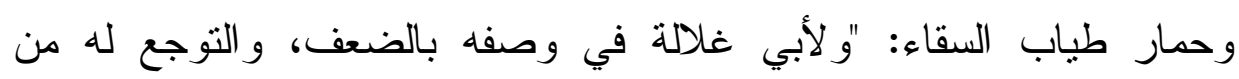

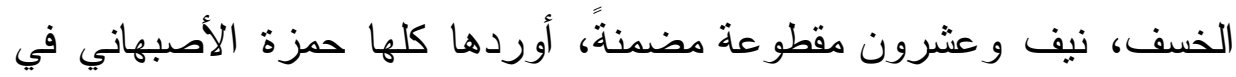

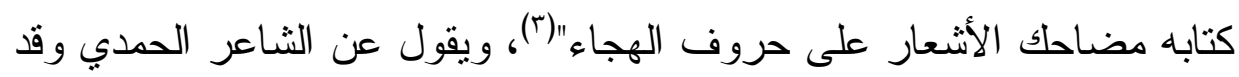

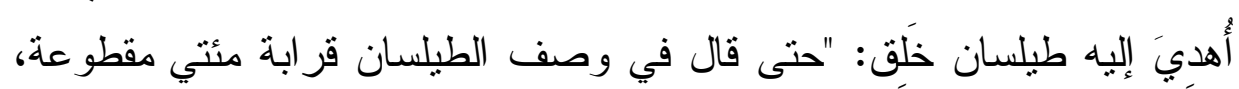

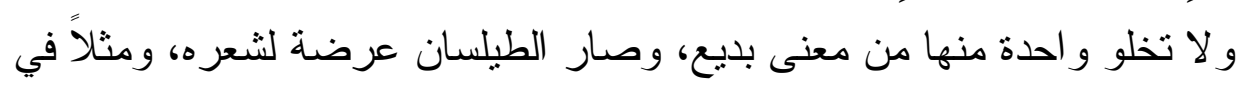

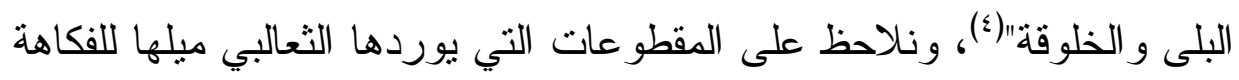

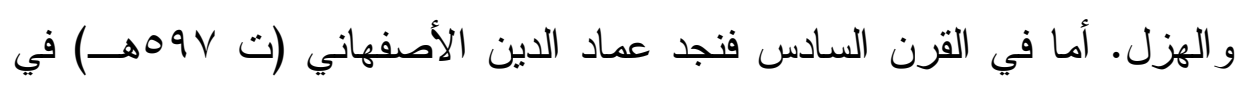

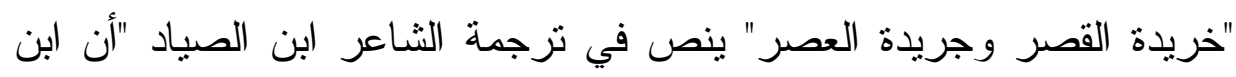

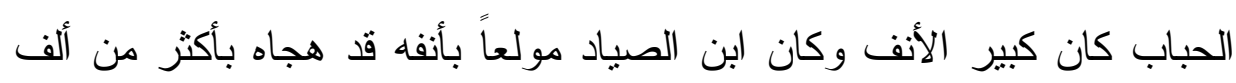

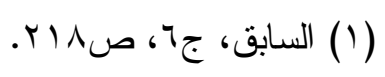

(r) أبو منصور عبد الملك بن محمد بن إنماعيل الثغالبي، يتيمة الدهر في محاسن أهل

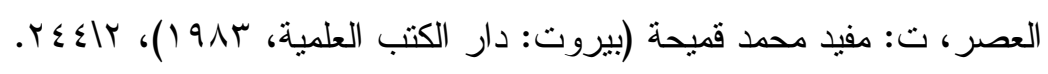

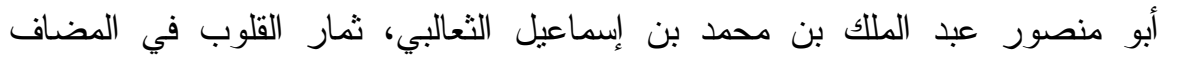

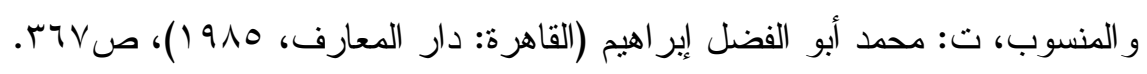

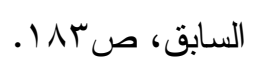




\section{د · جوخة الحارثي}

مقطوعةٍ وما كان يصده شيء" عنه"(')، وهنا مرة أخرى تزتبط المقطوعات بالمعنى الهزلي و الهجاء الساخر .

وفي القرن الحادي عشر نجد عبد القادر البغدادي (ت بو •اهـ) في

"خزانة الأدب" ينصُّ في بعض الأحيان على عدد أبيات المقطوعات التي يوردها؛ يقول مثنلا: "مقطوعة من تسعة أبيات لأبي ذؤيب الهذلي"(؟)" و "مقطوعة من ستة أبيات للمنتبي"(r)، ولا ينص أحيانا أخرى على العدد: "دقطو عة لامر أة من بني الحارث"(๕). كما يفرق البغدادي بوضوح بين القصيدة و المقطوعة، إذ نجد له هذا النص نقلا عن ابن الثجري: "وتصفحت نسختين من ديو ان عدي فلم أجد فيهما هذه المقطوعة، بل وجدت له قصيدة على هذا الوزن

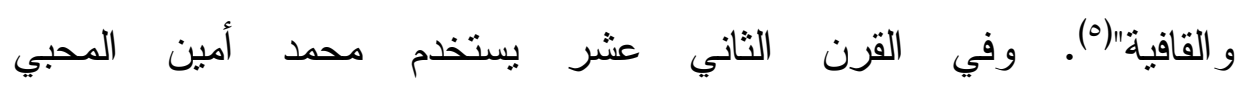
(ت. 11111 (اهـ) مصطلح "المقطوعة" في "نفحة الريحانة" متحدثا عن مئني مقطوعة قد قالها أحد الثعر اء في وصف طيلسان أهدي إليه(؟). وبالنظر في ارتباط المقطوعات الثعرية بموضوع الغزل، فإن مؤرخي الأدب يستخدمون مصطلح "الغزلية": يقول الباخرزي في "دمية القصر" متحدثا عن أبي الفرج حمد بن محمد بن حسنيل الهمذاني: "وأنثدني لنفسه من

(1) عماد الدين الأصفهاني، خريدة القصر وجريدة العصر، VNWw.alwaraq.net، ص ص

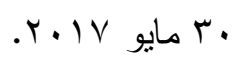

(Y) (Yبد القادر البغدادي، خز انة الأدب،

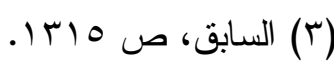

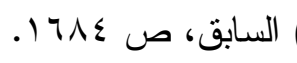

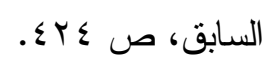

(7) محمد أمين بن فضل الله المحبي، نفحة الريحانة ورشحة طلاء الحانة، ت: عبد الفتاح

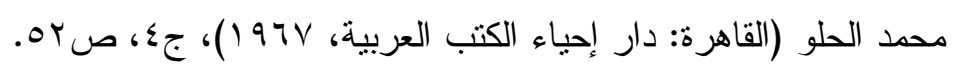


غزلية"()، ويورد لله مقطو عتين في الغزل، الأولى من سبعة أبيات و الثانية من

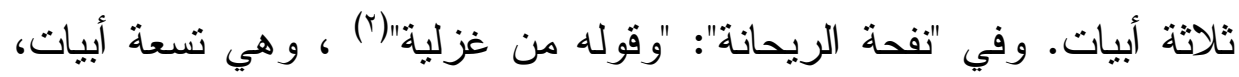

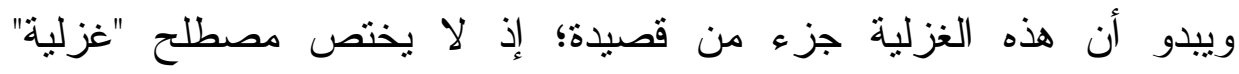
بالمقطوعة وحسب، بل توصف القصيدة أيضا بأنها غزلية، إذ يقول المرزوفي لإني

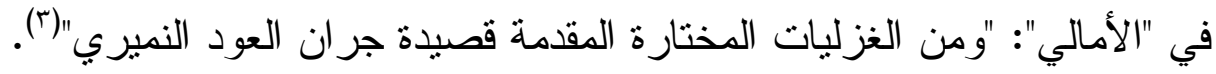

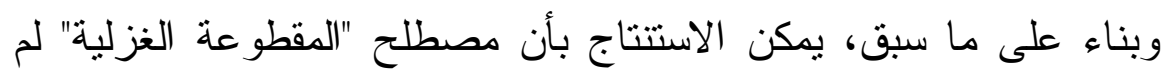

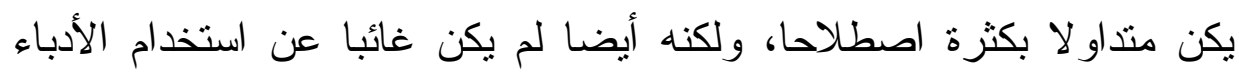

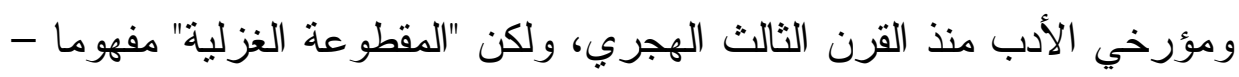

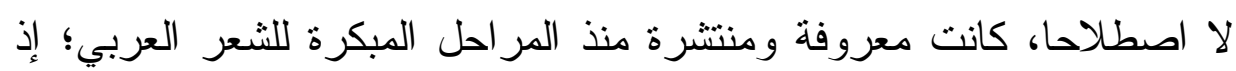

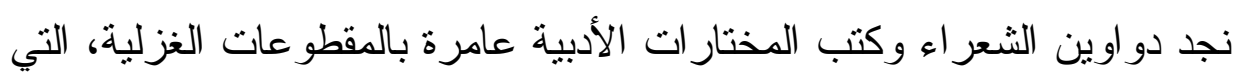
أتاح الغناء لكثير منها الذيوع و الانتتار كما سنوضح في المبحث القادم. الغناء وازدهار المقطوعات الغزلية:

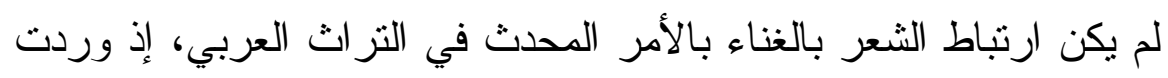
أخبار عدة تدل على شيوع الغناء منذ العصر الجاهلي، وعلى وجود القيان

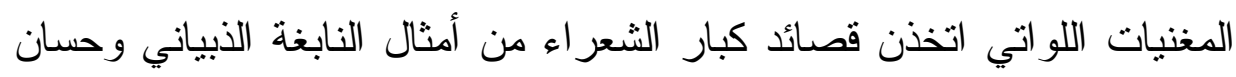

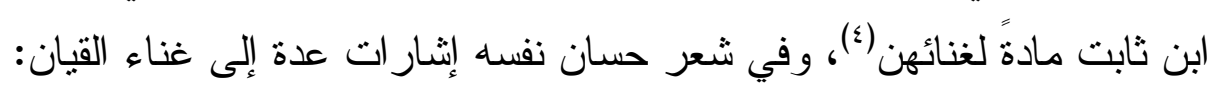

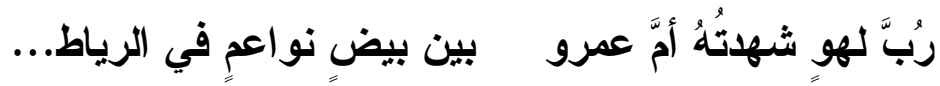

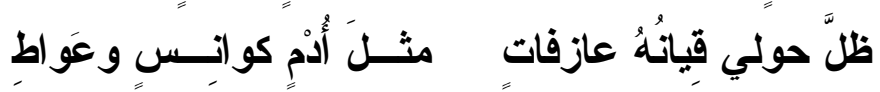

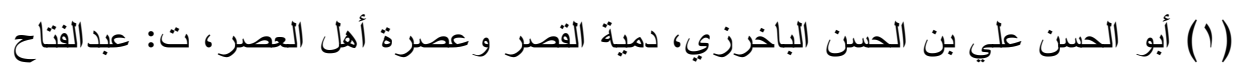

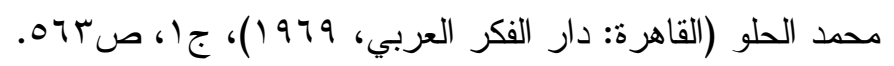

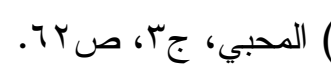

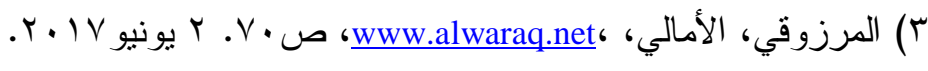

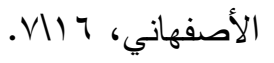




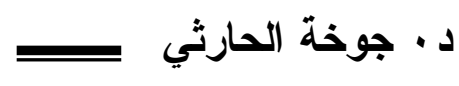

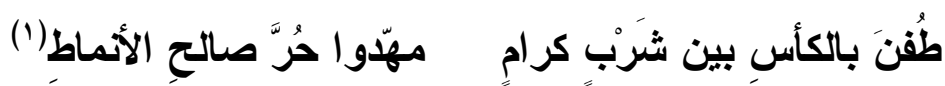

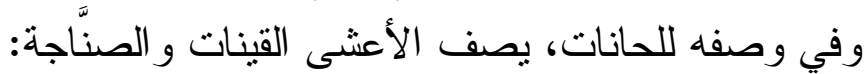

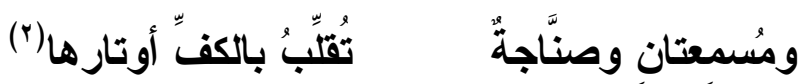

ويقول الأصفهاني عن عزة الميلاء: "كانت تغني أغاني القيان من القدائم

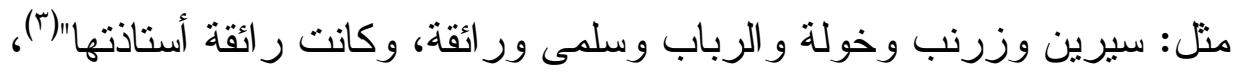

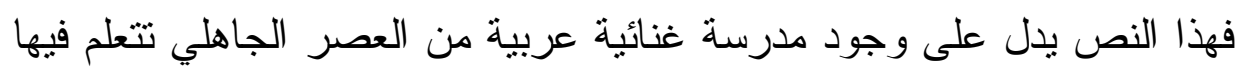

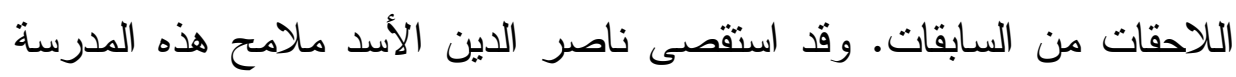

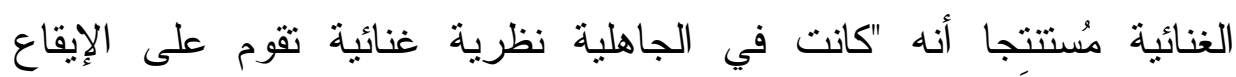

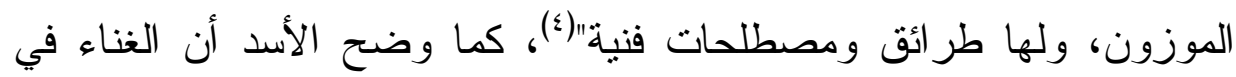
العصر الجاهلي لم يقتصر على ضرب واحد من البحور، بل شملها جميعا:

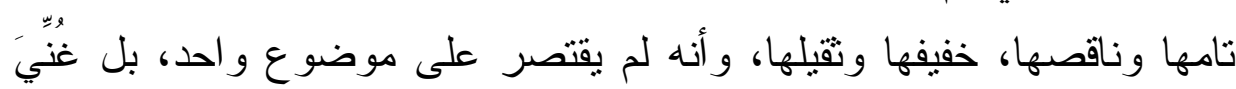
في المدح و الهجاء و الفخر و الغزل و الخمر (ه).

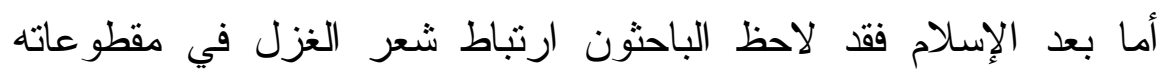

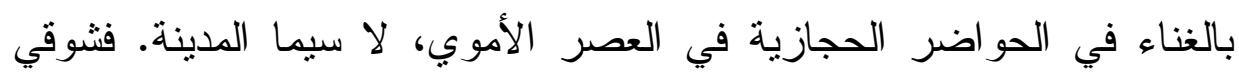

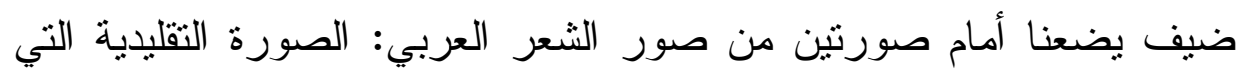
تعتمد ثقاليد كثيرة ومعقدة، وتمنلاها مطو لات الثعر العربي في المديح و الهجاء وما يتصل بهما، وصورة الأغاني، التي كانت في أكثر ها مقطو عات تدور حول

(1) حسان بن ثابت، ديوان حسان بن ثابت، ت: وليد عرفات (لندن: ستنفن أوستن وأو لاده،

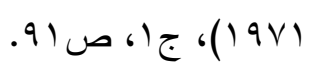

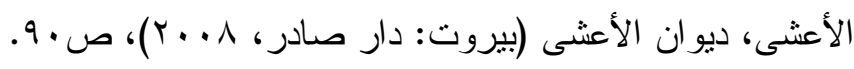

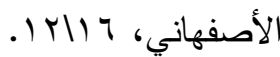

(أناصر الدين الأسد، القيان والغناء في العصر الجاهلي، طץ (القاهرة: دار المعارف،

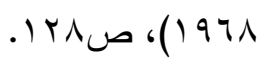

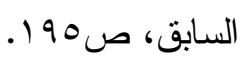


الغزل، وكانت تؤلف لتلدن وتغنى، وقد أسماها ضيف "الأغاني"((). و إن كان

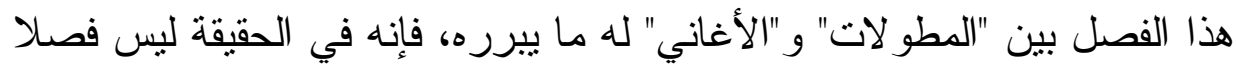

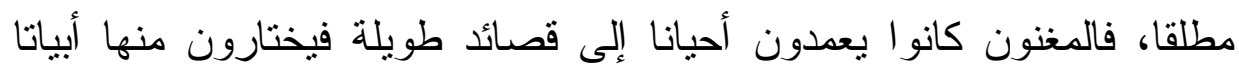

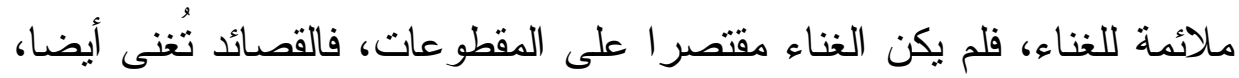
و لا أدل على ذلك من قصيدة عمر التي مطلعها:

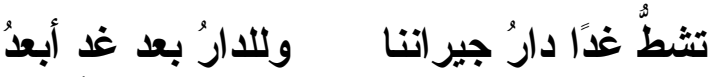

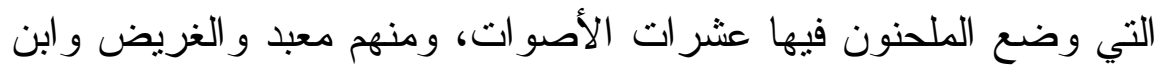

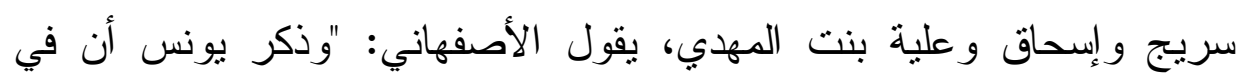

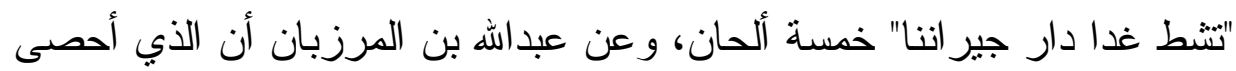

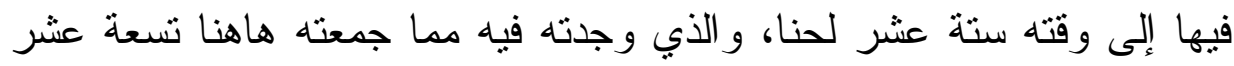
لحنا"(؟). وهذا يكثف إلى أي حد كان شعر عمر رائجا في الغناء.

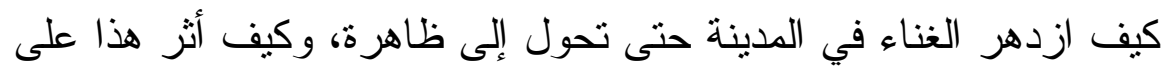
نمو فن المقطوعة باعتباره فنا مستقلا عن القصيدة؛ بروي اليعقوبي أن المدينة

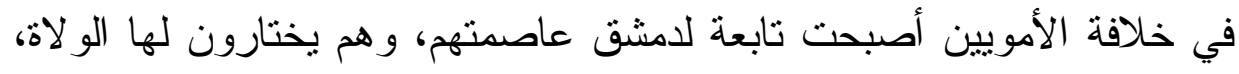

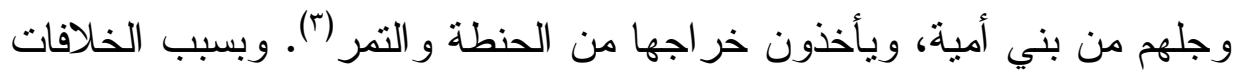

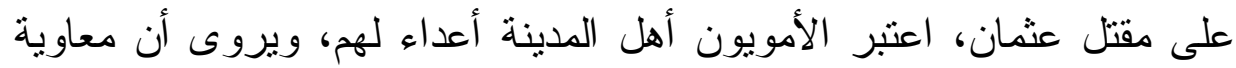

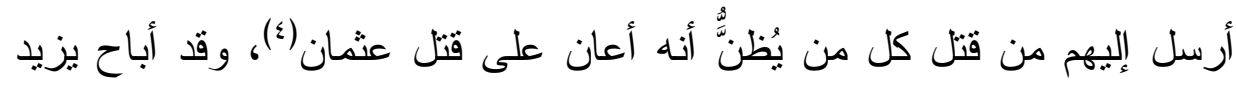

(1) شوقي ضيف، الثعر و الغناء في مدينة ومكة لعصر بني أمية، طع (القاهرة: دار

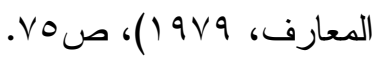

$$
\begin{aligned}
& \text { الأصفهاني، (Y) }
\end{aligned}
$$

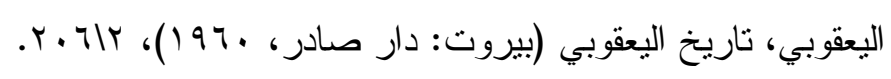

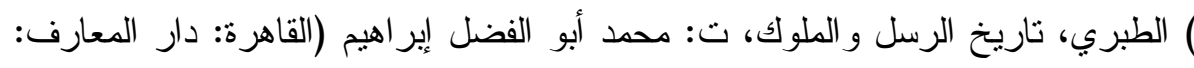




\section{د. · جوخة الحارثي}

لجيثه المدينة ثلاثة أيام في وقعة الحرة(')، واستمرت علاقة المدينة مضطربة بالأمويين، نتيجة الإقصاء السياسي الذي تعرضت له، ولكن هذا الإقصاء السياسي قابله ازدهار مادي، بدت بوادره منذ استهلال الفتوح في عهد عمر، و ازداد في عهد عثمان لييلغ أوجه في حكم بني أمية. وإن كانت المصادر القديمة منل الأغاني و المستطرف و العقد الفريد تستقيض في وصف مظاهر التزف و الرفاهية في حياة أهل المدينة(؟)، فإن شوقي ضيف ينقل لنا كثير ا من تلك النصوص مستشهدا بهاب(")، وكأنها حقيقة لا تحتمل المبالغة، متجاهلا رغبة المؤلفين القدامى في إبهار المتلقي ومداعبة خياله بأطياف الترف و ألوان النعيم. على أن الدلالة الرمزية في هذه النصوص - على الرغم من مبالغاتها السردية - تظل ماتلةة، وهي التتويه إلى ما اكتنف حياة المدينيين من فر اغ ولهو، مدا جعل الفراغ السياسي يُملأ بالفن، وتُصرف إليه الأمو ال و الأوقات.

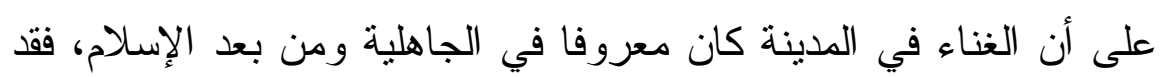
استُقبل به الرسول صلى الله عليه وسلم أول دخوله المدينة(ء)، ثم بدأ الصحابة و التابعون يختلفون في إجازته وتحريمه؛ يخبرنا ابن عبد ربه بخبر دال في هذا

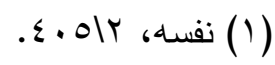

(Y) يروي الأصفهاني على سبيل المثال: وقال إسحاق بن إبر اهيم في خبره حدثي محمد بن

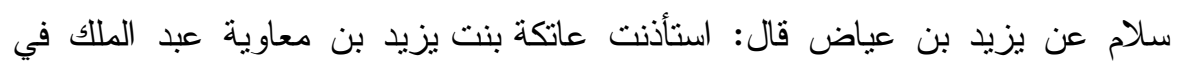

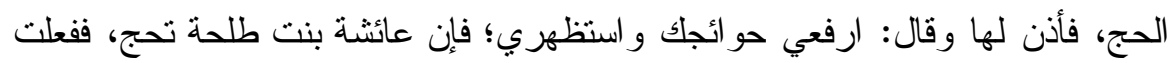
فجاءت بهيئته جهدت فيها. فلما كانت بين مكة و المدينة إذا موكب قد جاء جاء فضغطها

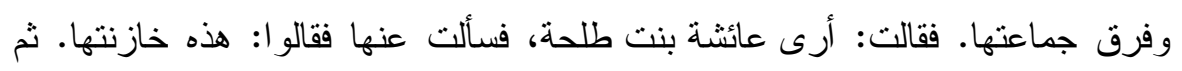

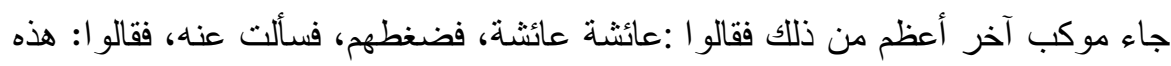
ماشطتها. ثم جاءت مو اكب على هذا إلى سننها ـ ثم أقبلت كوكبة فيها ثلاثمائة راحلة

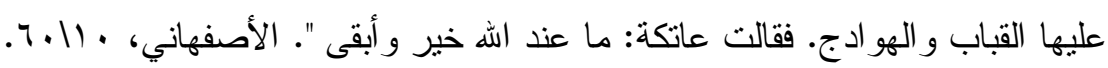

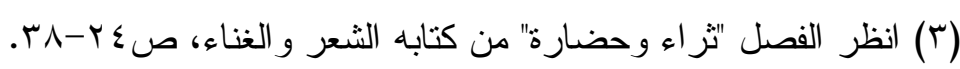

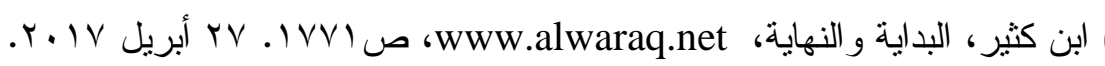


السياق: "اختلف الناس في الغناء فأجازه عامة أهل الحجاز وكرهه عامة أهل

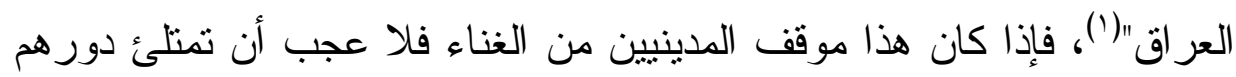

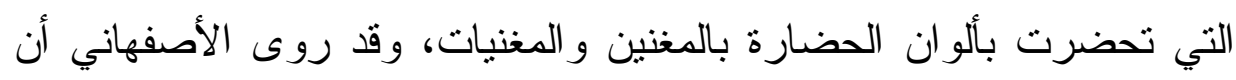
عبدالله بن عامر في عصر عثمان اثتترى إماء صناجات وأتى بهن إلى المدينة

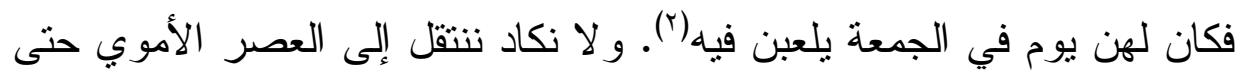

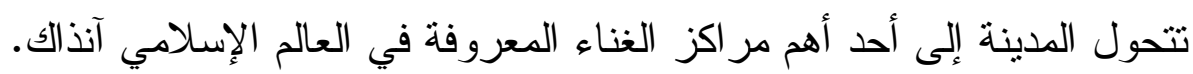

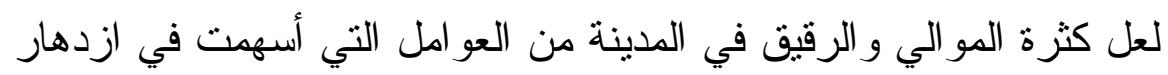

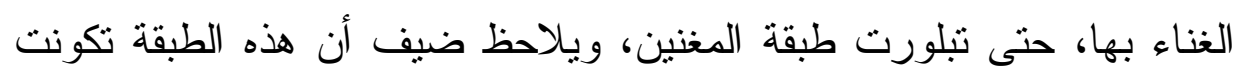

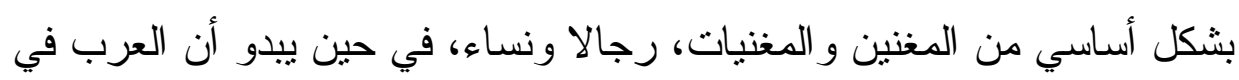

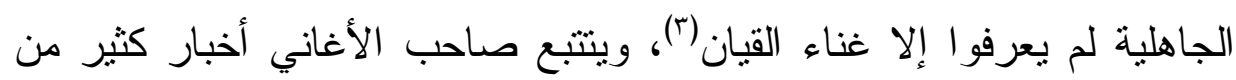

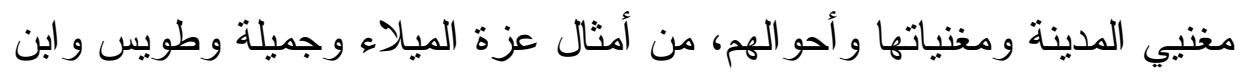

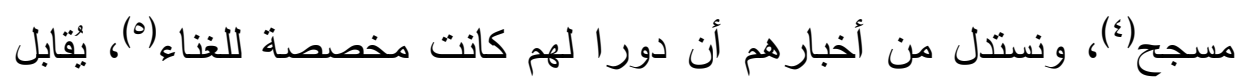

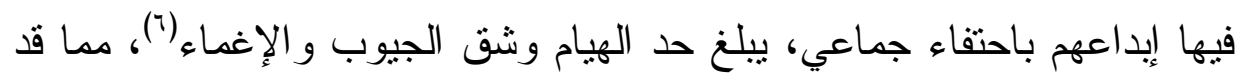
(1) ابن عبد ربه،العقد الفريد، تح: محمد سعيد العريان (القاهرة: مطبعة الاستقامة، .ـ؟9)،

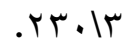

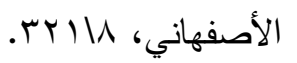

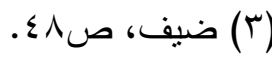

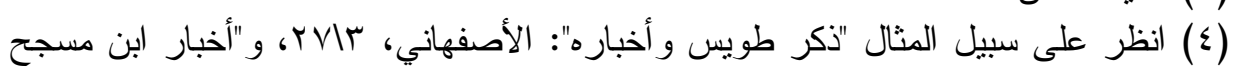

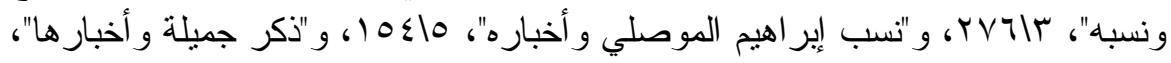

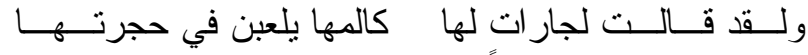

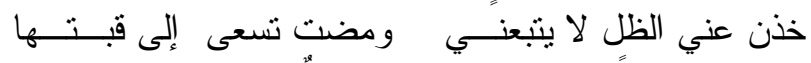

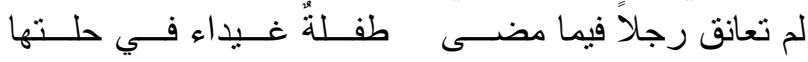

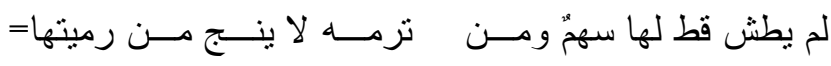




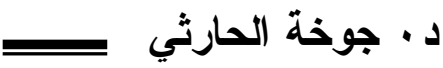

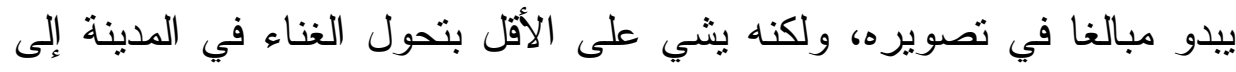

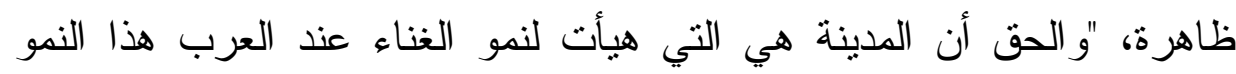
الذي جعله يتحول من صناعة بسيطة إلى صناعة معقدة لها تقاليدها ورسومها،

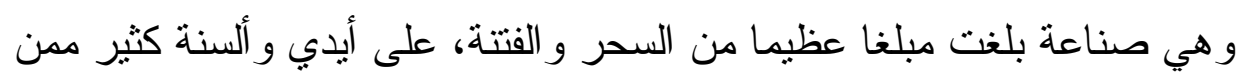

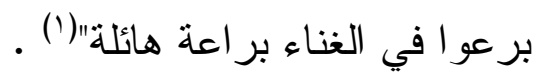
ولم يكن الحال في مكة بمختلف عما كان عليه في المدينة من حيث الثراء

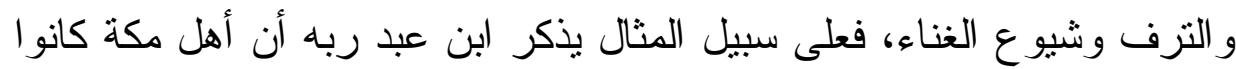

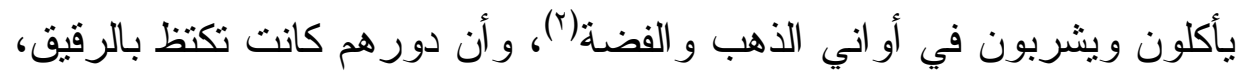

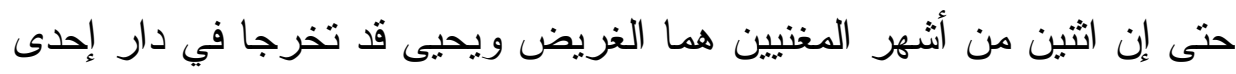

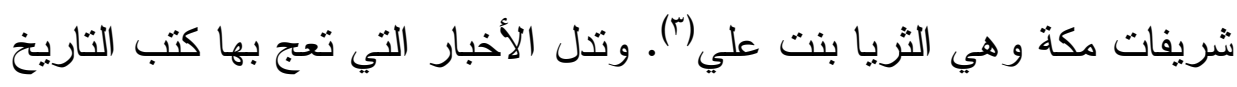

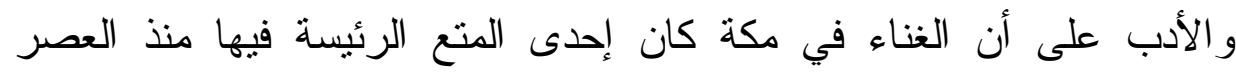

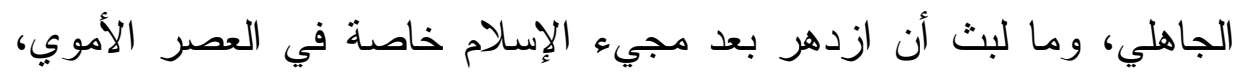

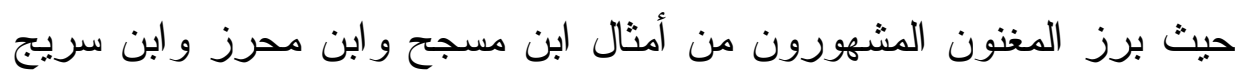

=لم يذكر طريقة لحنها في هذا الصوت. وذكر الهشامي أن فيه لابن الككي رملا

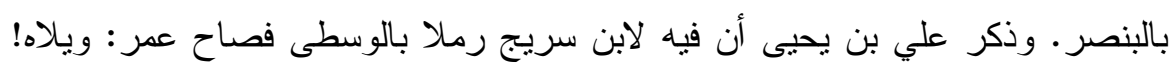

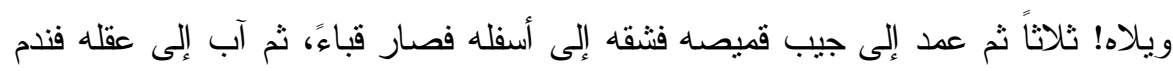

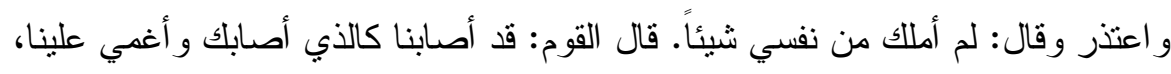

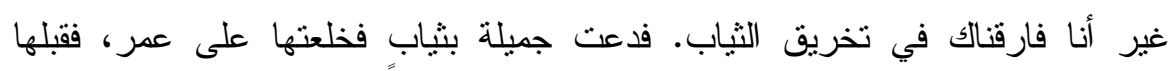

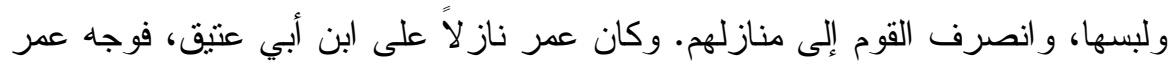

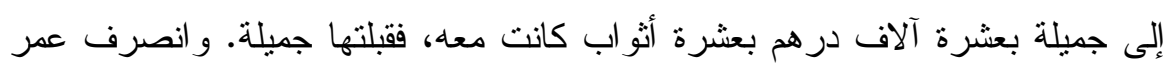

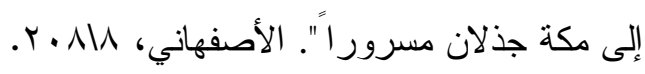

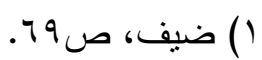

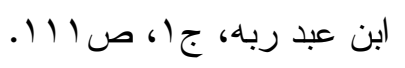

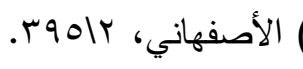




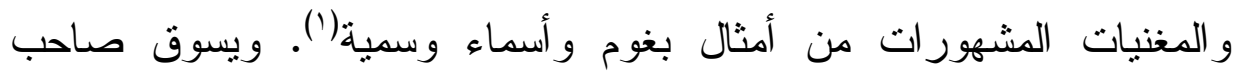
الأغاني أخبار ا تشير إلى أن دائرة التلقي للغناء في مكة لم تكن محصورة التهاء

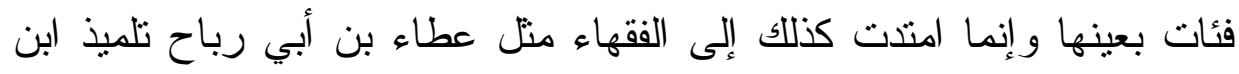

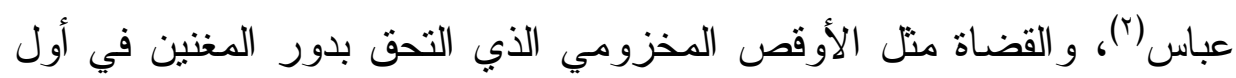

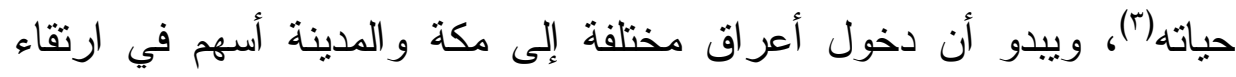

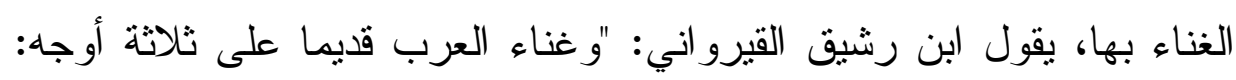

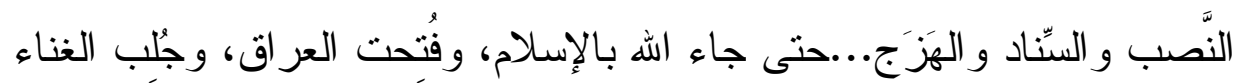

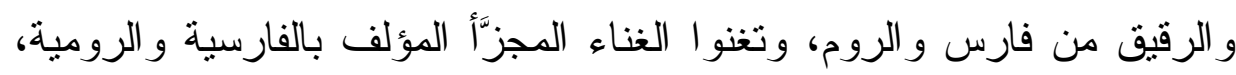

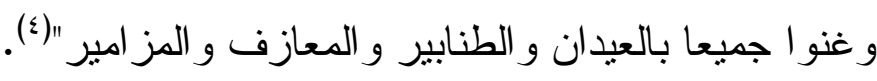

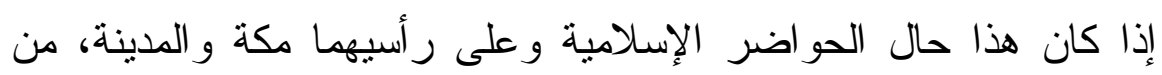

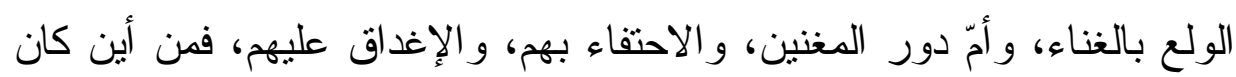

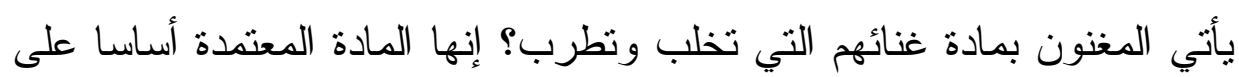

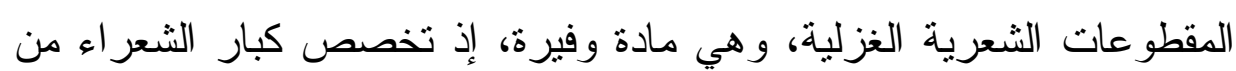

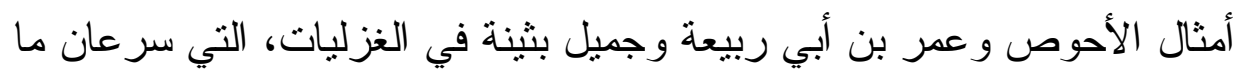

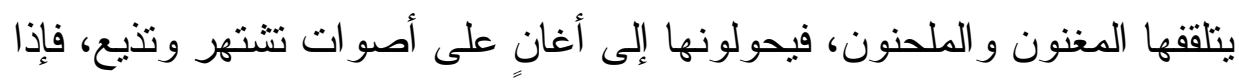

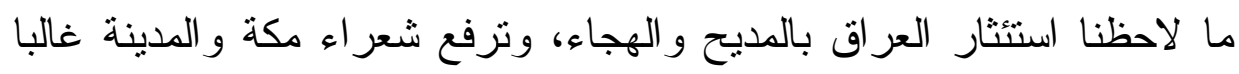

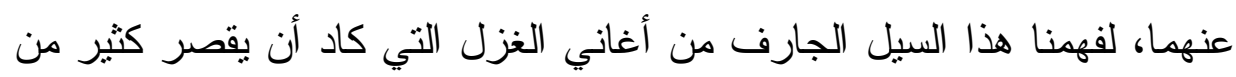
شعر اء الحجاز أنفسهم عليها.

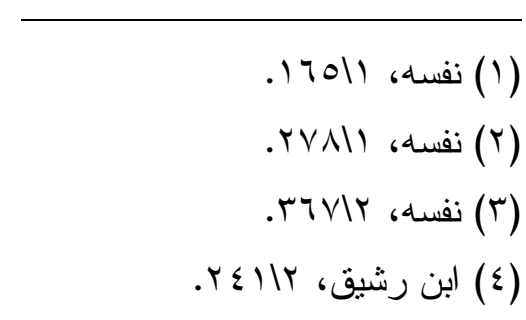




\section{د. · جوخة الحارثي}

ليس من قبيل إذن المصادفة أن يزدهر فن المقطوعات الغزلية على يد شاعر لا يُشك بشاعريته ولا يُنازع فيها، يرتضيه النقاد و الثعر اء على حد سواء، هو عمر بن أبي ربيعة، الثاعر المكي من بني مخزوم: "سمع الفرزدق شيئا من نتبيب عمر فقال: هذا الذي كانت الثعر اء تطلبه فأخطأنه وبكت الديار" (') ولما روى جرير أبياته:

سائلا الربعَ بالبلي وقولا هجتَ شَوقا لي الغداةَ طويلا

قال: إن هذا الذي كنا ندور عليه فأخطأناه و أصابه هذا القرشي"(؟) .

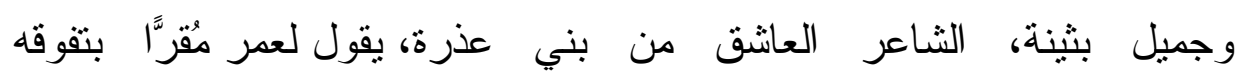

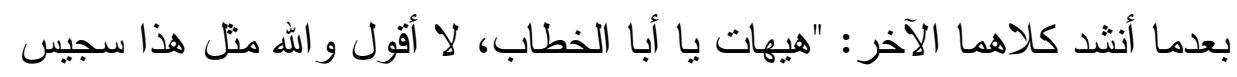
الليالي"(r). قال الزبيري عن مقطوعته التي غناها ابن سريج ومطلعها:

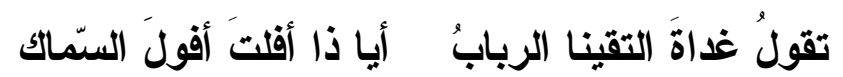

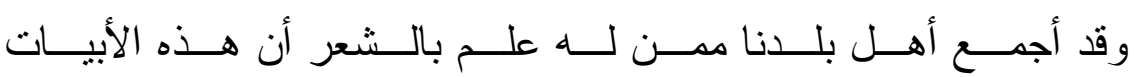

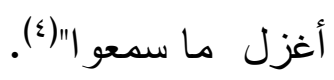

كل هذه الأخبار وغيرها تدل على أن عمر بن أبي ربيعة كان يحظى بقبول نقدي، جعله مؤهلا ليكون فارس الغناء، ولا ريب أنه كان يدرك أن أن أن المقطوعات الغزلية لها السهم المعلى في هذا السوق الر ائج، وقد كان هو نفسه

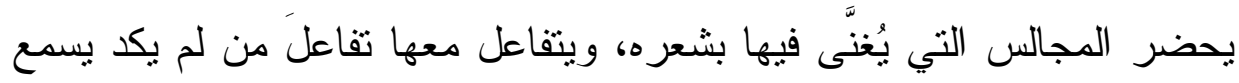
بالشعر من قبل، وكأن الغناء بشعره وتلحينه قد أعطاه قيمته المطربة، وهي

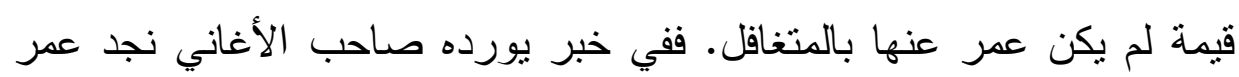


يلحق بجميلة المغنية من مكة إلى المدينة، وحين يحضر مجلسها للغناء، تغني من شعره:

هيهاتِ من أمة الوهَّابِ منزلنَا إذا حكلنَا بسيفِ البحرِ من عدنِ

وتوصف ردة فعل الثناعر :"ودمعت عينا عمر حتى جرى الادع على ثيابه

ولحيته، و إنه ما رئي عمر كذلك في محفل قط"('). وبالنظر في ديوان عمر بن أبي ربيعة نجد أن الديوان بحتوي على خمس وستين ومائة قصيدة، وست

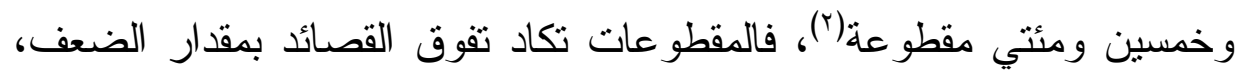
ومن الجلي أنها كانت تثير الاهتمام والجدل النقدي أو الديني، وثبرز خصائص شعر عمر كما تبرزه القصائد فمقطو عته التي تتنهي بالبيت:

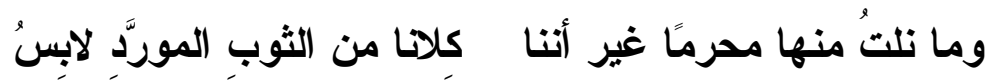
هي مقطوعة غناها المغنون، ولم يحل قصر أبياتها من أن تثير النقاش مع

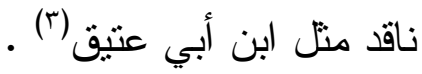
إن المقطوعات التي يوردها صاحب الأغاني لعمر بن أبي ربيعة كلها لحِّنَت وغُنيت، البساطة في اللغة و التشبيب في العاطفة و الحوار في القصة الثعرية تتجلى في المقطو عات كما تجلت في القصائد؛ ففي مقطو عته:"طالَ ليلي وتعنَّني الطرب"، قصة منكاملة ولحنا ملائما للغناء، فيها لحن للحمان ومعبد و ابن سريج(؛). وهي مشفو عة في الأغاني بقصة تفسر ها وتتبني عليها(ه). وكما تدور قصائده حول التشبيب ببنات البيوتات من شريفات مكة، كذللك تقعل

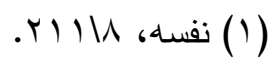

$$
\begin{aligned}
& \text { (r) عمر بن أبي ربيعة، ديوان عمر بن أبي ربيعة، تح: عبدالرحمن المصطاوي (بيروت: }
\end{aligned}
$$

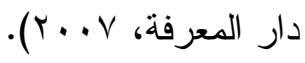

$$
\begin{aligned}
& \text {.VAll نفسه }
\end{aligned}
$$

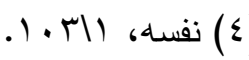

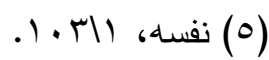




\section{د · · جوخة الحارثي}

مقطو عاته الغزلية، فهي مكرسة للتغزل بنساء علية القوم من أمثنال فاطمة بنت

عبد الملك بن مروان(')، و عائشة بنت طلحة'(r).

إذن، صغر حجم المقطوعة مقارنة بالقصيدة لم يَحُل دون أن ثتجلى فيها

خصائص شعر عمر، فكم من مقطوعات هي حكايات مغامرات حب، وعلى

سبيل المثال يورد صاحب الأغاني تسعة أبيات مشفوعة بقصة رجل يهوى ابنة

عم لله ساعده عمر على نزوجها مطلعها:

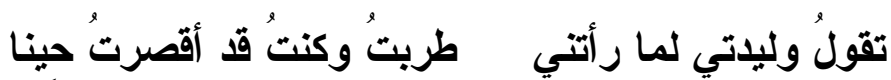

غناها ابن سريج وفيها ثقيل أول للغريض وفيه لاحمان خفيف رمل(r) . فالبساطة والاثتمال على حكاية من مميزات مقطوعات عمر الغزلية منل المقطوعات في محبوبته هند التي جاءت على أوزان خفيفة وللملحنين فيها شغل كثير(£). ويبدو أن المغنين كانوا يستشعرون الحرية في تطويع الثعر للغناء، فهم يجتزئون المقطوعات التي تروقهم من القصائد، بل ربما يغيرون القافية

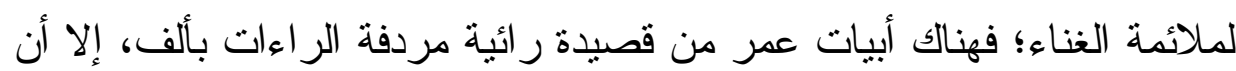
المغنين غيروا هذه الأبيات فجعلو ا مكان الألف كافا. وهي الأبيات التي أولها: لقد أرسلت جاريتي وقلت لها خذي حذرك، و أصلها "خذي حذر ا"(ه).

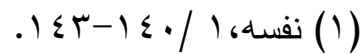

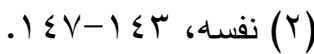

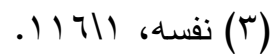

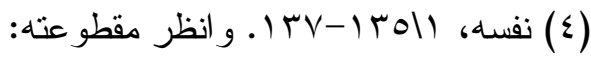

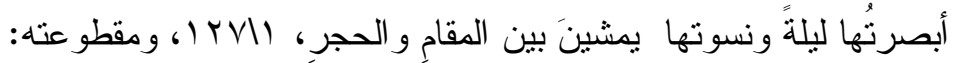

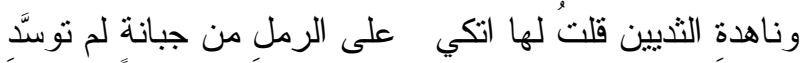

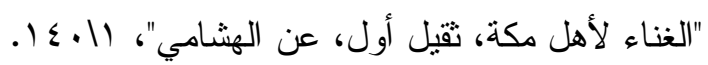


ويبدو أن كثرة هذه المقطو عات المغنّاة هي ما دفعت ضيف إلى الاستتناج

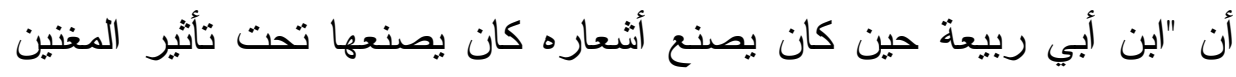
و المغنيات...ولم يكن هذا شأن عمر وحده إنما كان شأن بقية الثنعر اء المكيين

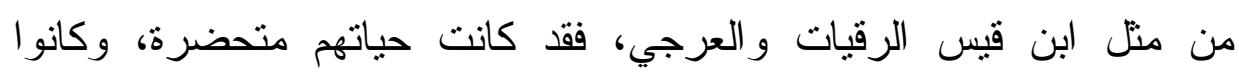
يعيشون للشعر و الغناء وهذا النرف الذي أصاب المكيين في العصر الأموي"( (1).

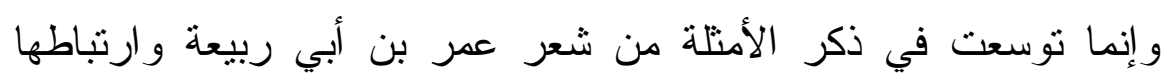

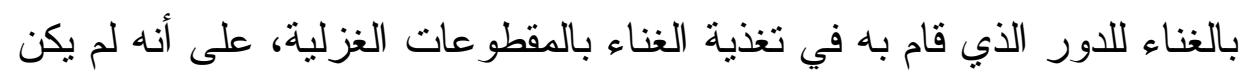

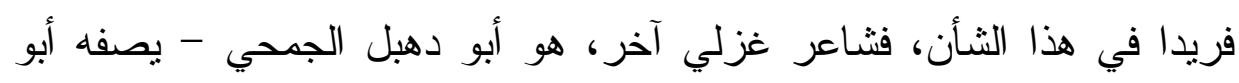

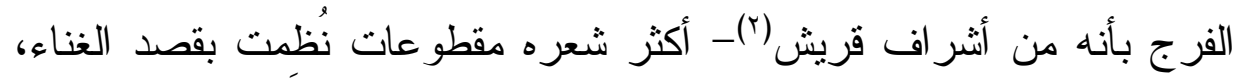

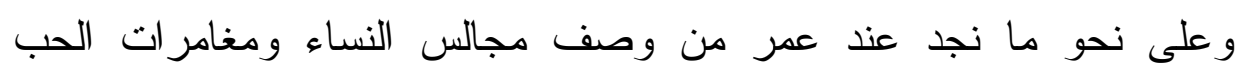

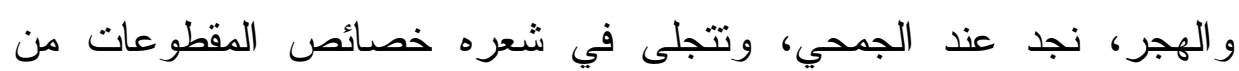
البساطة و اللين وسهولة الألفاظ.

أما الثعراء العثاق العذريون فأكثروا كذلك من المقطوعات الغزلية،

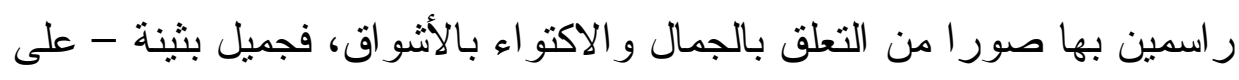

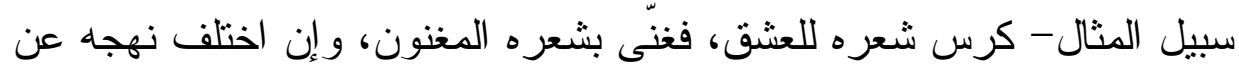

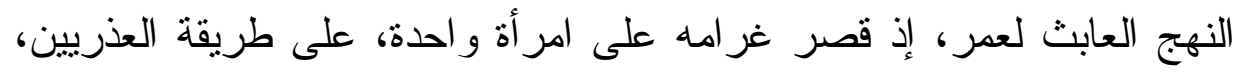

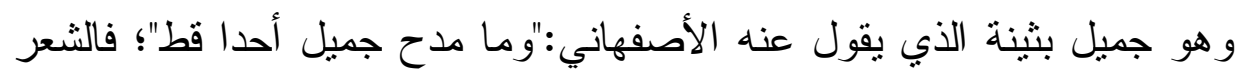

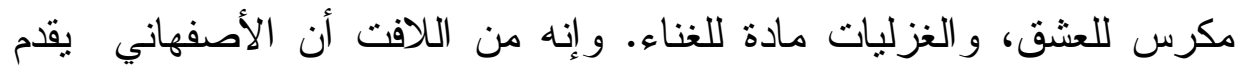

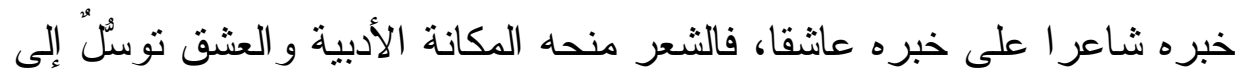

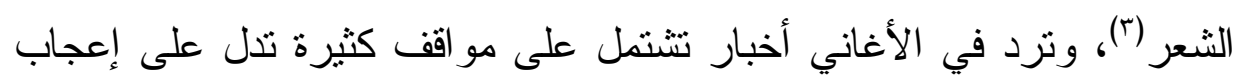

(1) ضيف، Y)

(Y) الأصفهاني، (Y)

(r) نفسه، (Y) 


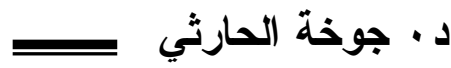

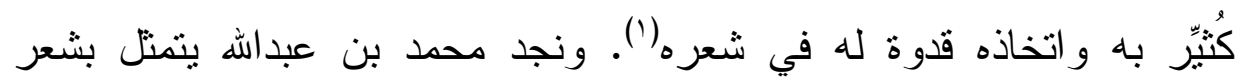

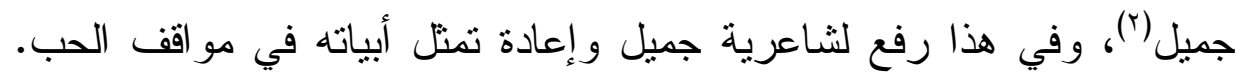

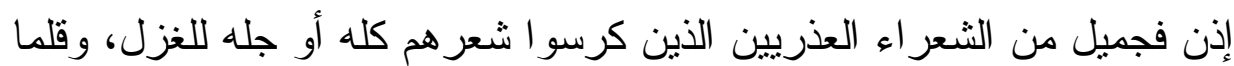

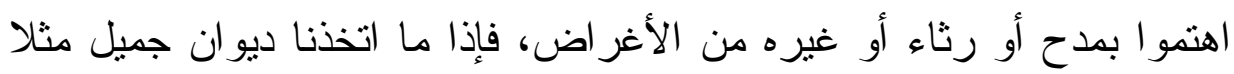

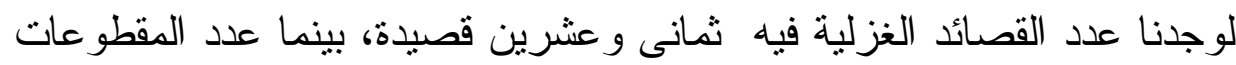

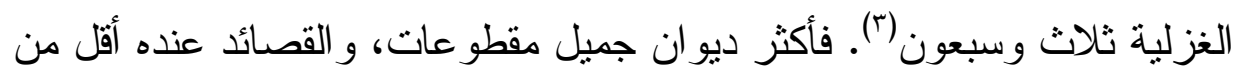
المقطوعات، وإذا كان الغناء - كما نستتف من كتاب الأغاني- قد شمل قصائده ومقطو عاته()، فإن للمقطو عات السهم الأوفر في هذا الغناء.

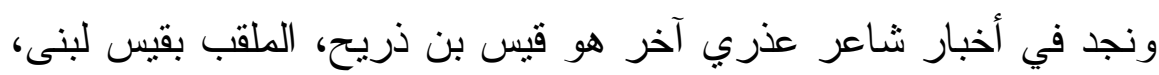

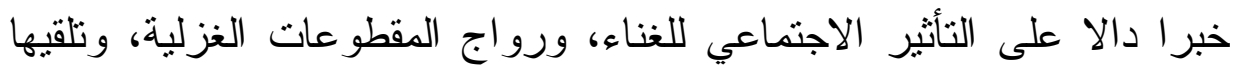

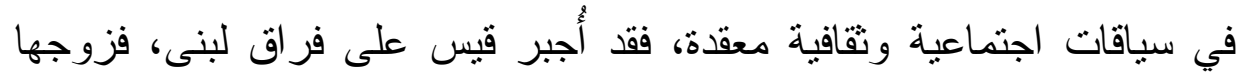

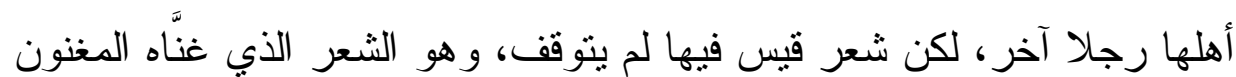

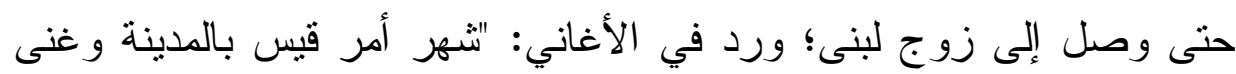

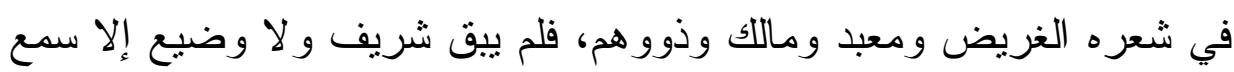
بذلك فأطربه وحزن لقبس مما به. وجاءها زوجها فأنبها على ذلك و وعاتبها

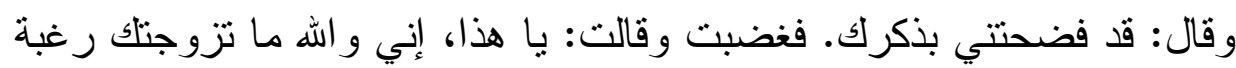

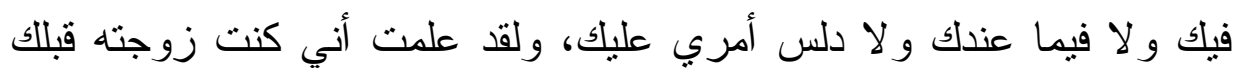
وأنه أكره على طلاقي. وو الله ما قبلت التزويج حتى أهدر دمه إن ألم ألم بحينا،

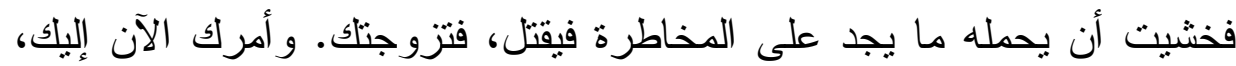

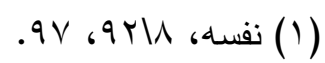

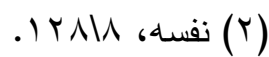

(ץ) جميل بثينة، ديوان جميل بثينة، تح: فوزي عطوي ، طب (بيروت: دار صعب، 
ففارقني فلا حاجة بي إليك. فأمسك عن جوابها وجعل بأتيها بجواري المدينة

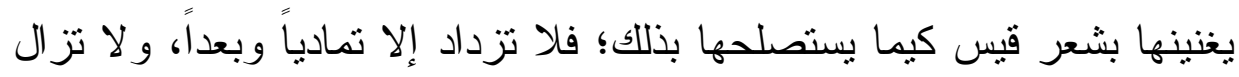

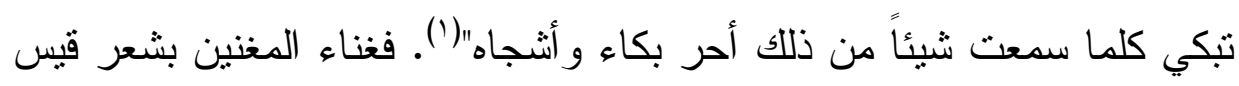

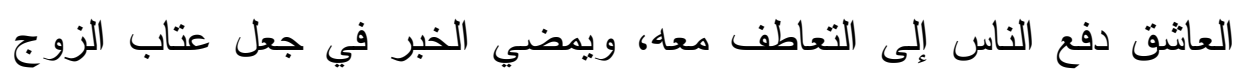

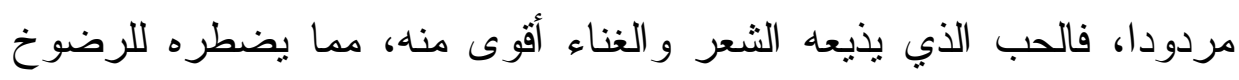

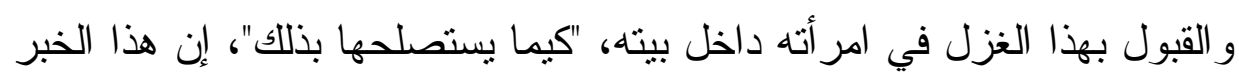

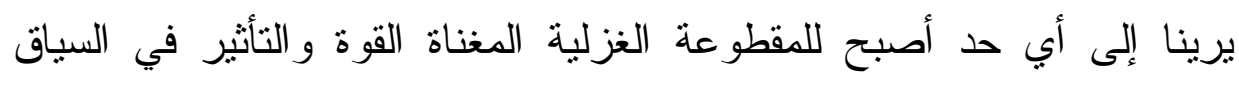
الاجتماعي و الثقافي في العصور الإنسامية المبكرة، ولعل طواعية القطعة

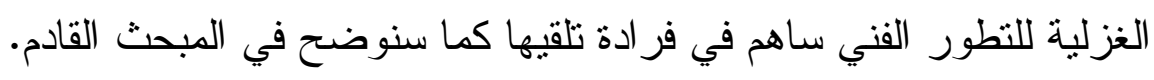

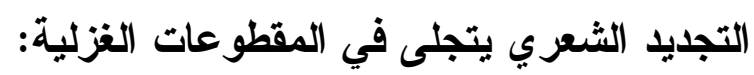

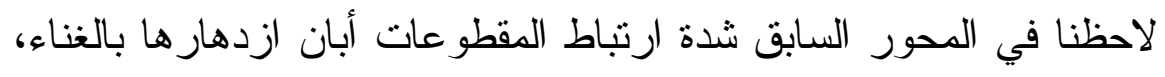

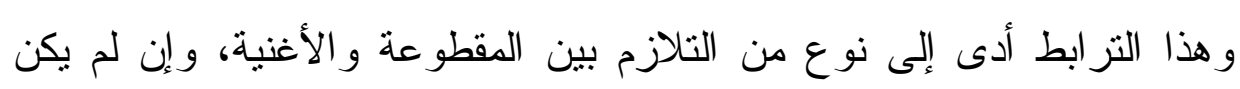

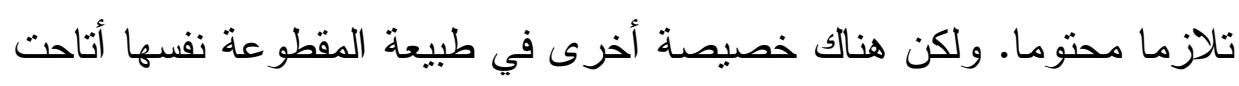

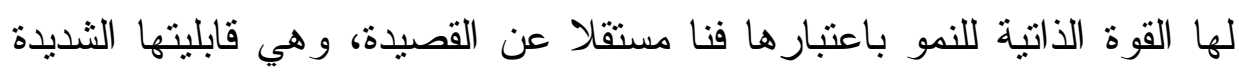
للتطور وملائمتها لأذواق العصور المختلفة، وتحمل أبياتها القصيرة لمعانٍ

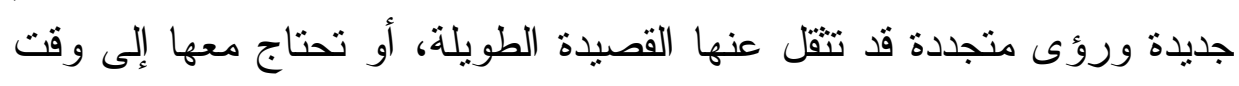
طويل حتى تتضج وتتشرب الألوان الحديثة من التعبير الثتعري.

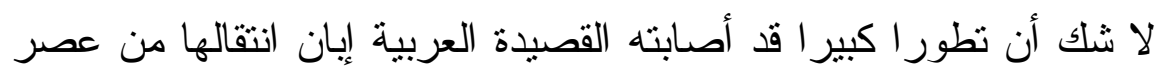
إلى آخر ومن طور إلى طور، ولكنها كانت واقعة عموما تحت وطأة الثقاليد

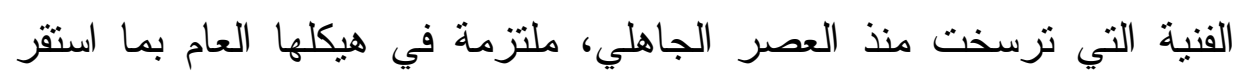




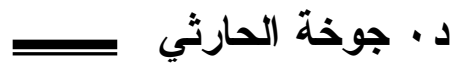

عليه الثعر اء وباركه النقاد، على نحو ما نعرف من نص ابن قتتية الثهير (')،

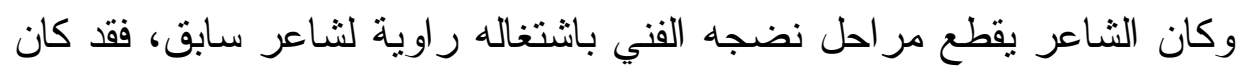

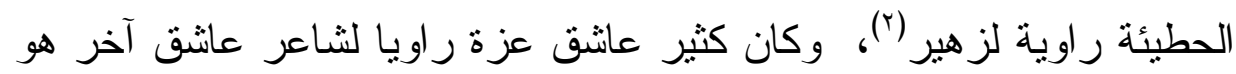

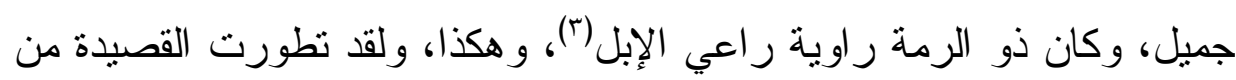

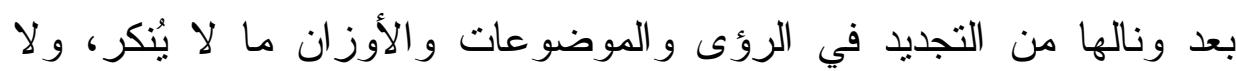

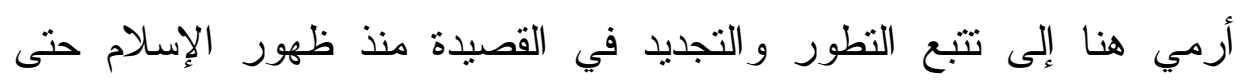

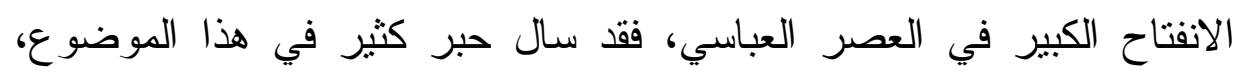

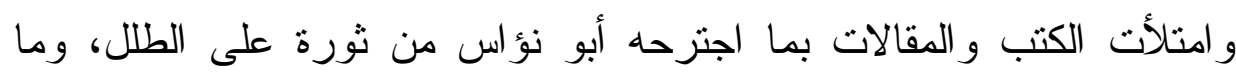

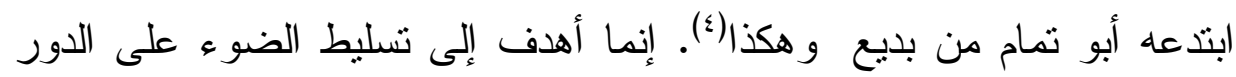

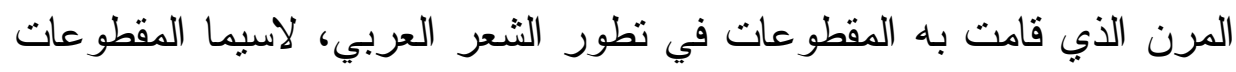

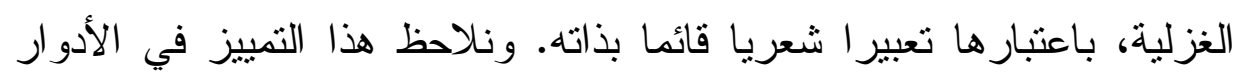

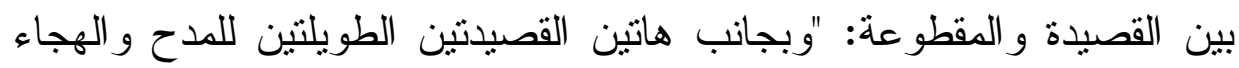

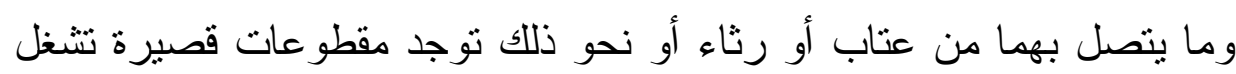

(1) يقول ابن قتيبة: "وليس لمتأخر الثعر اء أن يخرج عن مذهب المتقدين في هذه الأفسام،

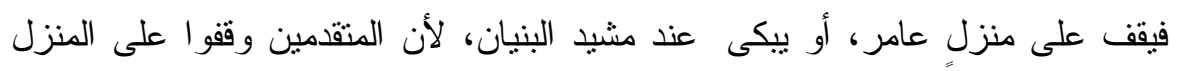

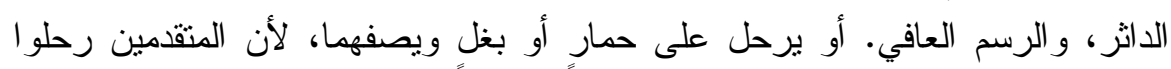

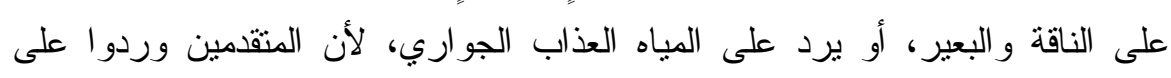

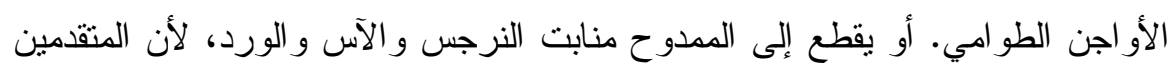

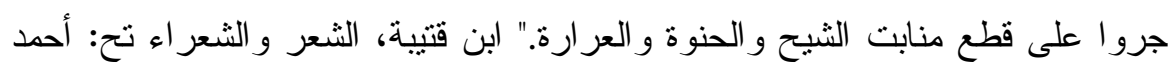

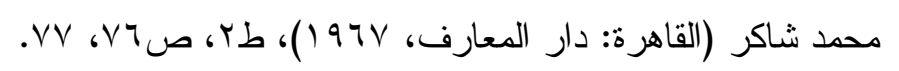

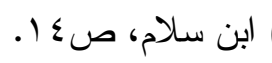

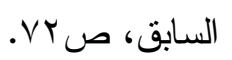

(ع) انظر - على سبيل الدثال - كتاب عز الدين إسماعيل، في الثعر العباسي الرؤية والفن

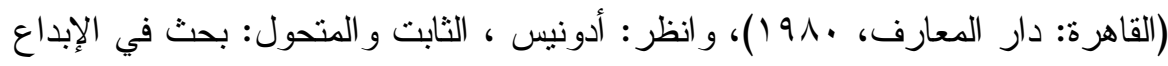

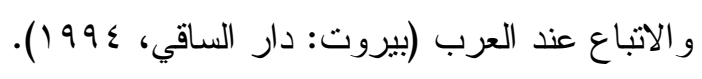


الغزل عادة...و أكثر هذه المقطوعات يدل بصورته على أنه لم يُقل ليُنشد في سوق عكاظ و غير ها من أسواق العرب، و إنما قيل ليُغنَّى" ('). لاحظ الباحثون - في إطار المقارنة بين المقطوعة و القصيدة- اللغة التها

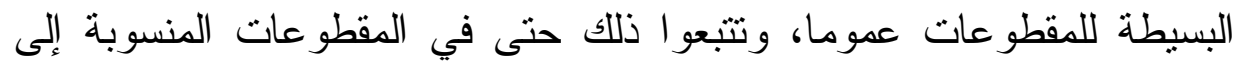
شعر اء جاهليين مثل امرئ القيس، إذ يشير بدوي إلى أن مقطوعته في رثناء أبيه

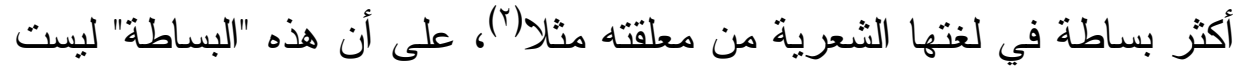

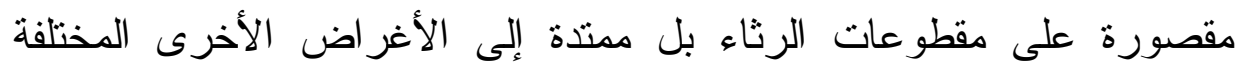
للمقطوعة، ولا بد هنا من الإثارة إلى اللغة البسيطة التي تميزت بهاه

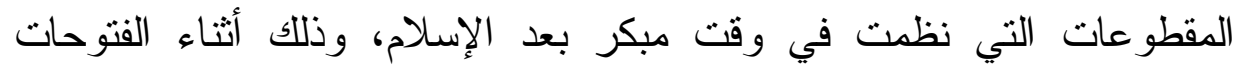

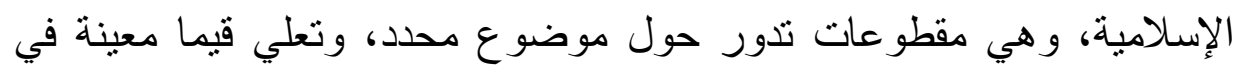
أبيات معدودة، ميسورة الحفظ والإنثاد، مما يقودنا إلى التفكير بأنه إذا كان

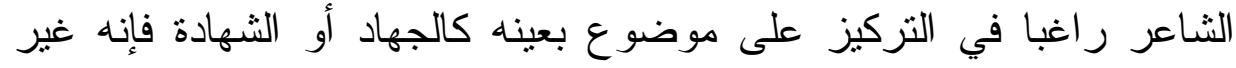
مضطر إلى التزام التقاليد الفنبة المعقدة للقصيدة الكلاسيكية، وبالتالي فاتجاهه

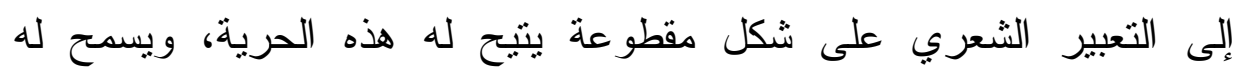
بالتركيز على فكرة واحدة بلغة أكثر بساطة وأوزوان أكثر خفة (؟). وهناك عامل آخر أسهم في مرونة المقطوعات الثعرية وقابليتها للتجديد

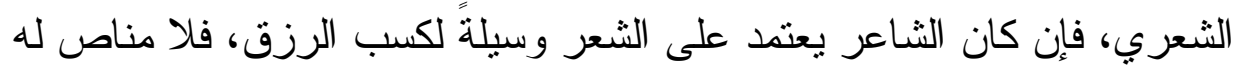

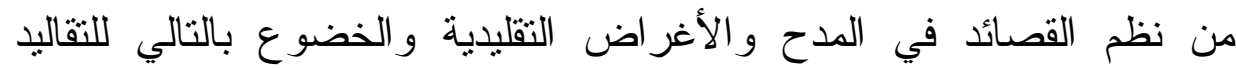

( $Y$ ) M. Badawi, "From Primary to Secondary Qasidas: Thoughts on the Development of Classical Arabic Poetry", Journal of Arabic Literature, vol.1। (191.), p). تجلى هذا بوضوح فيما بعد في شعر الخوارج الذي كان أغلبه على شكل مفطوعات تدور حول قيم الجهاد والاستشهاد و الحق و العدل ومقاومة الظلم، انظر إحسان عباس،

$$
\text { شعر الخوارج، طץ (بيروت: دار الثقافة، ع } 9 \text { ـ ( ). }
$$




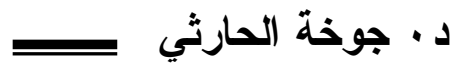

الثعرية الرسخة، للوصول إلى المعايير النقدية الدقبولة المستقرة في ذائقة

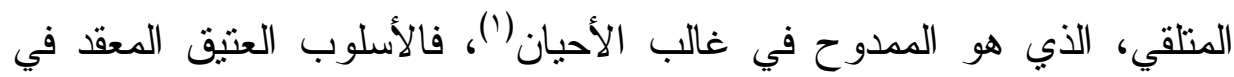
المدحيات يُرجى منه ملائمة ذوق الأمر اء الذي تربى على على الاحيان النماذج الكلاسيكية للشعر القديم وثم نيل عطاياهم، في حين أن هذه القيود من التقاليد الأدبية

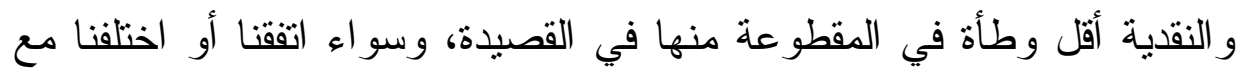
بدوي في كون الثاعر ينظم المقطوعة لإمتاع نفسه فقط أو التعبير عن مشاعره

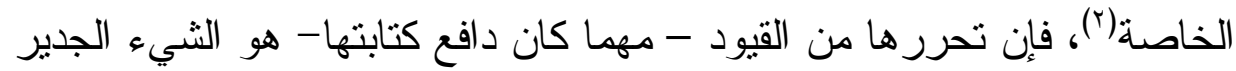

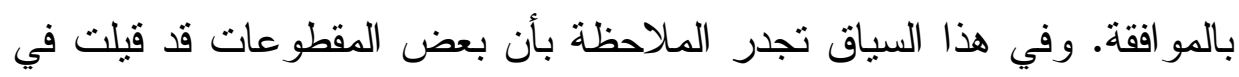
سياق الفكاهة و الهزل، إذ أورد ابن عبد ربه في العقد الفريد هذه الحكاية: "قال

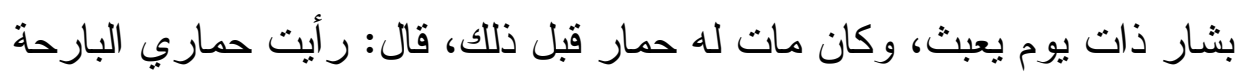

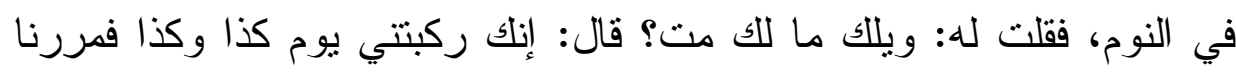

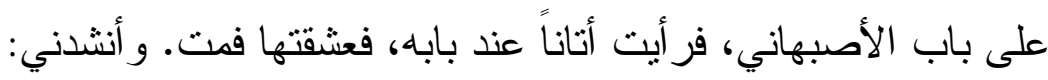
سيدي مل بعناتسي نحو باب الأصبهاني

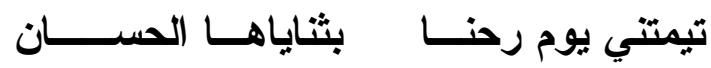

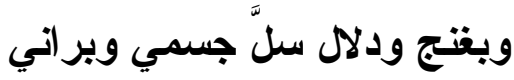

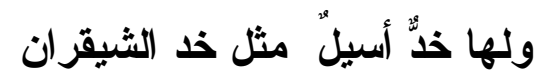
فبها مت ولو عثت إذن طال هواني

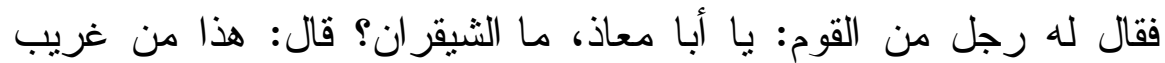

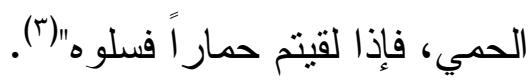
يمكن بالتأكيد ملاحظة العبث في هذه المقطوعة العة الهزلية، ولكن تجدر

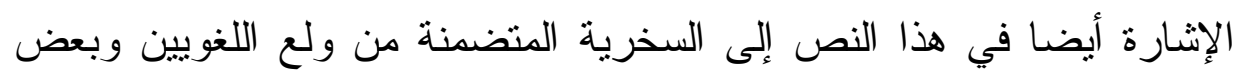

( ) Badawi, p. Ir.

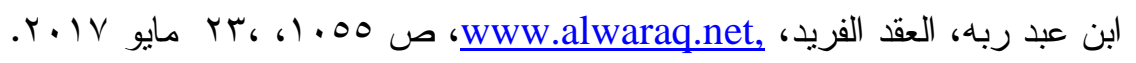


الثعر اء بالغريب، بنسبة كلمة غير معروفة إلى ما أسماه بشار ساخرا

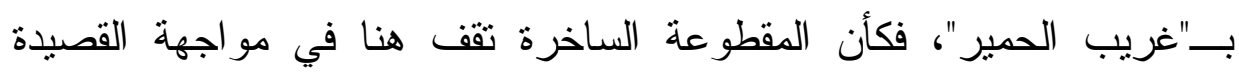
الجادة، تحمل المقطوعة من غريب الحمير ما تحمله القصيدة من غريب اللغة.

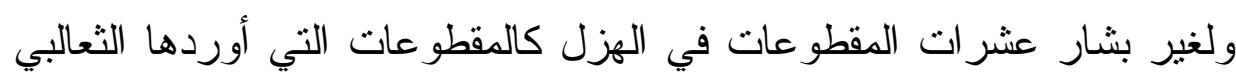
لأبي غلالة المخزومي في حمار الطياب السقاء ('). وإن كانت بعض مقطوعات الحماسة المنسوبة للعصر الجاهلي قد دارت

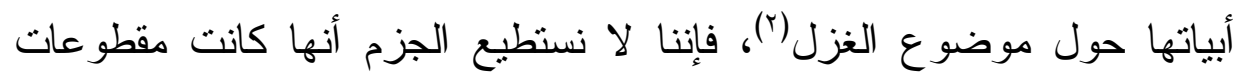
مستقلة وليست أجز اء من قصائد، في حين ينطور هذا الفن بعد الإسلام ليزدهر

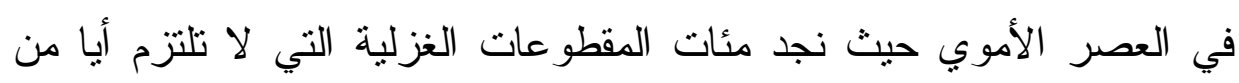

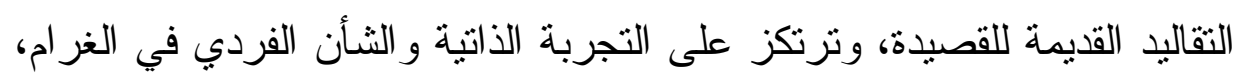

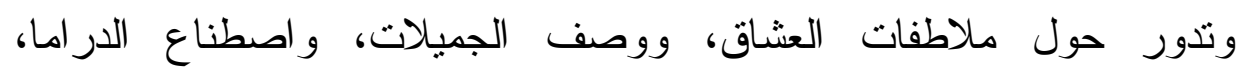

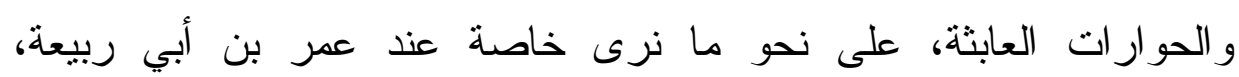

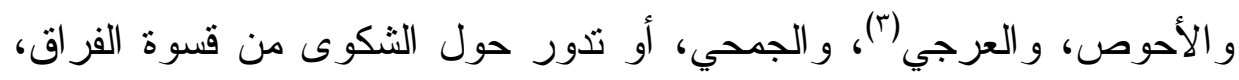
(1) - (1) فمنها على سبيل المثال: يا سائلي عن حمار طياب ذالك حمار حليف أوصاب

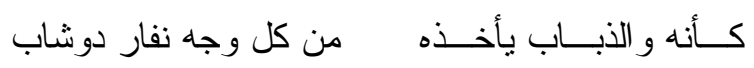

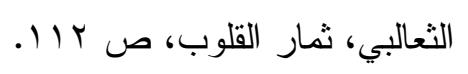

(r) انظر على سبيل المثال المقطوعة المنسوبة إلى عبداله بن عجلان النهاي في الحماسة،

$$
\text { ومطلعها: }
$$

$$
\begin{aligned}
& \text { وحُقة مسكِ من نساء لبستُها شبابي وكأسِ باكرتني شَمَولُها }
\end{aligned}
$$

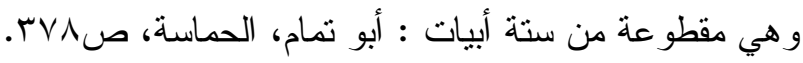

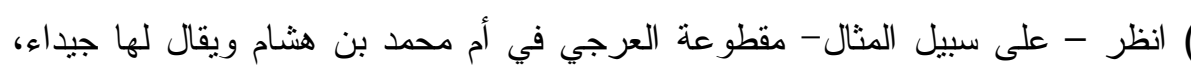

$$
\begin{aligned}
& \text { ومطلعها: }
\end{aligned}
$$

عوجي علينا ربة الهودج إنكِ إلا تفعلي تحرجي

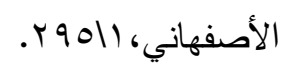




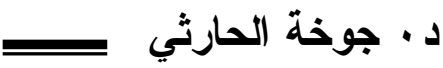

وعذاب الحب، و إبطال المواعيد، و آلام الثوق، على نحو ما نرى عند جميل بثنينة وقيس لبنى وغير هما من الثعر اء العذريين، فالمقطوعة الغزلية أبيات

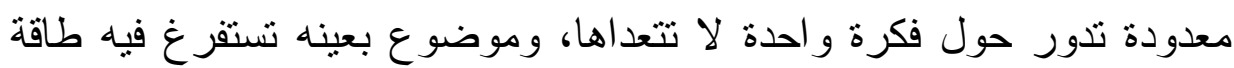
أبياتها القصبرة. يقول جميل بثنينة:

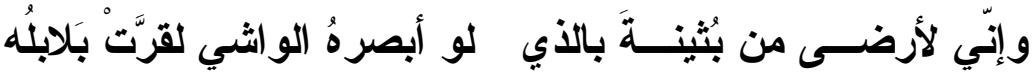

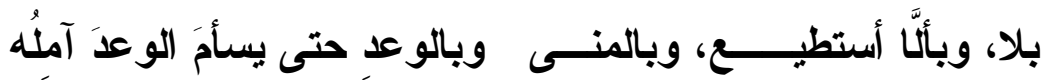

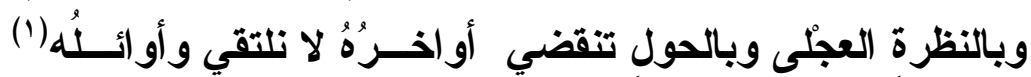

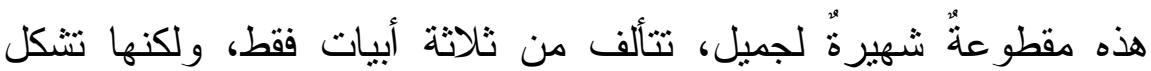

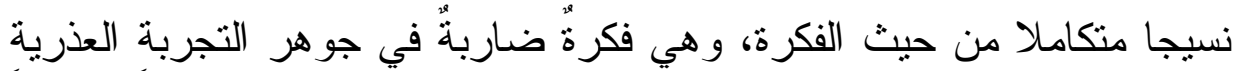
في الحب، حيث العاثق يدور في فللك المحبوبة الواحدة الفريدة، لا يكاد يكون

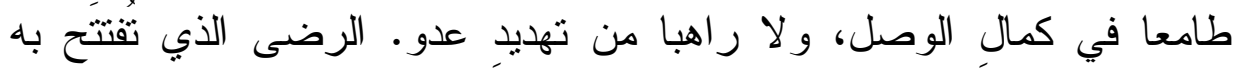

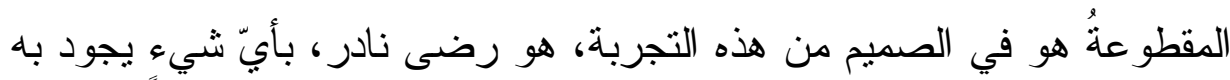

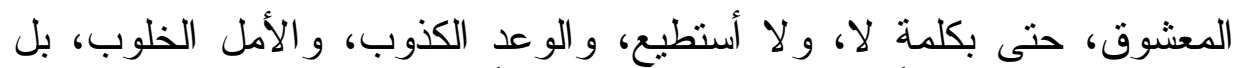

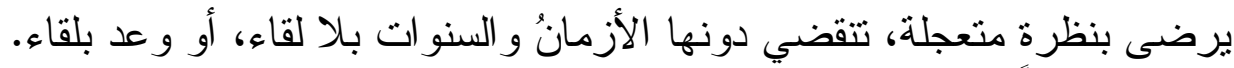
هذا الحب المطلق، و الأملُ في أقل ما يمنحه الحلم، يعبر عنه جميل في ثلانثة

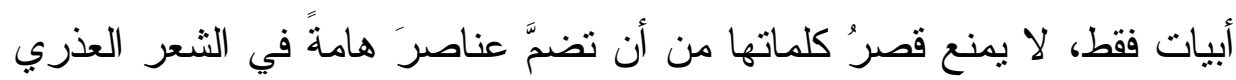

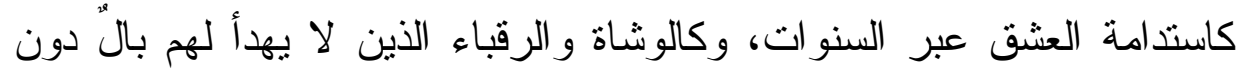

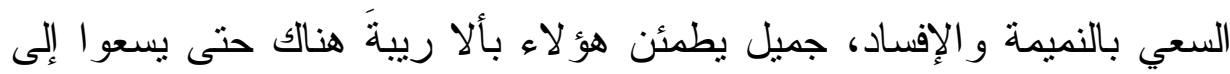

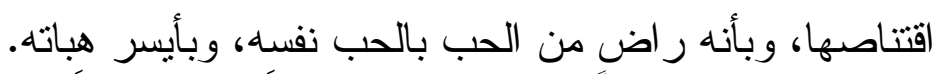
فهنالك إذن في المقطوعات الغزلية - على اختلاف نوجهاتها - التركيز

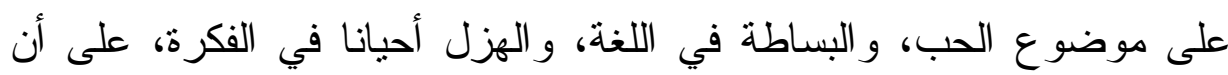
المقطوعات الغزلية تميزت فوق ذلك بخفة الأوزان الثعرية، فأكثرها على الى الثيان 
الرمل و الهزج و المتقارب، ويلاحظ ضيف الارنباط الوثيق لهذه الظاهرة

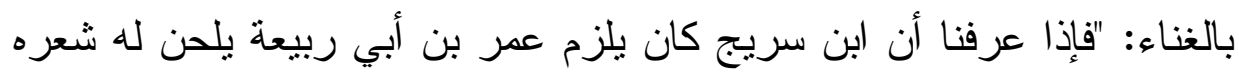

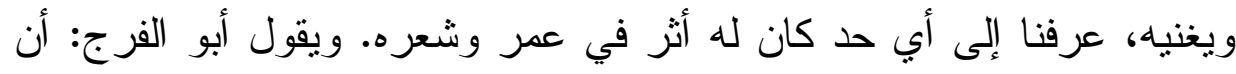

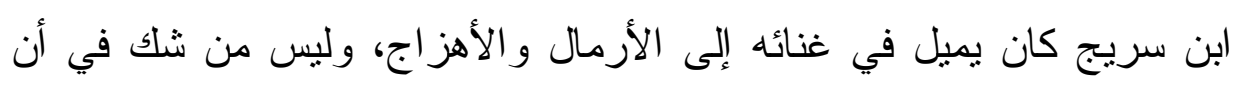
هذا هو السبب الصحيح في أن هذين الوزنين اللذين ينذمجان اندماجا تاما في لأني

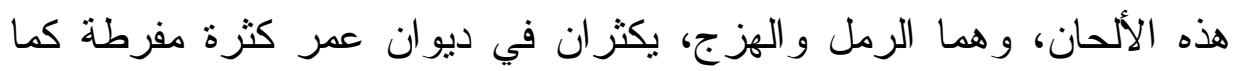

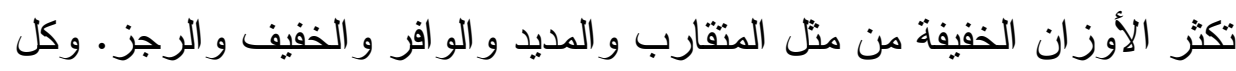

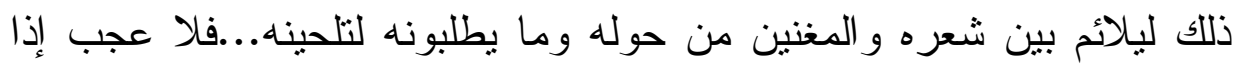

وجدنا ديو انه يمتاز بظاهرة الموسيقى الخفيفة والأوزان السهلة القريبة"( (1).

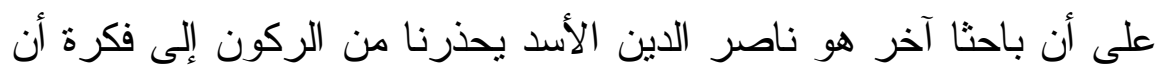

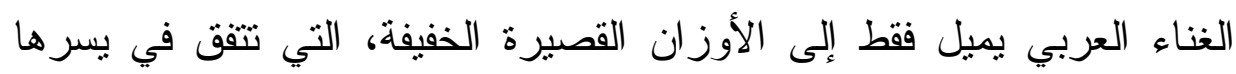

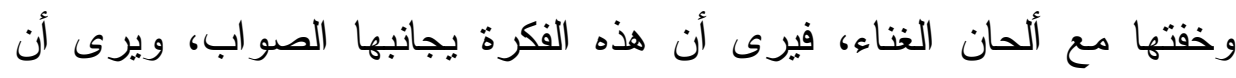
البحور غير التامة من مجزوء ومشطور ومنهوك لم تكن تجديدا غنائيا في

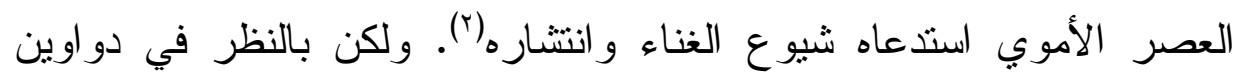

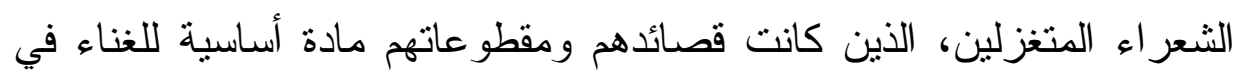

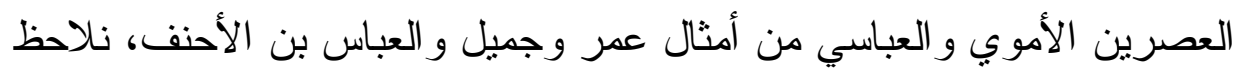

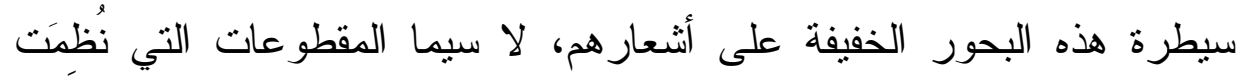
لتُغنَّى أصلا.

يبدو أن التجديد في المقطوعات الغزلية، قد استقر على ما يثبه التقاليد

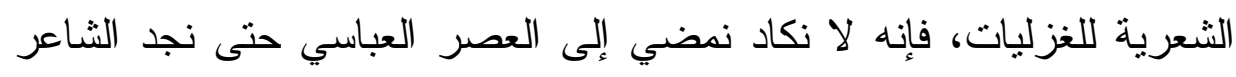

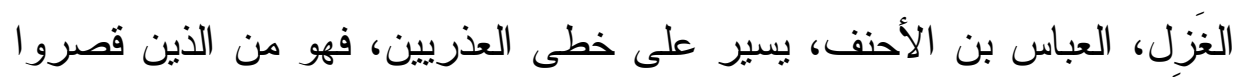




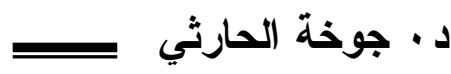

شعرهم على الغزل، وقد اثتهرت مقطوعاته برقتها، وتغني المغنون بها ، فقد الهاتي سمع إبر اهيم الموصلي غناء في قول العباس:

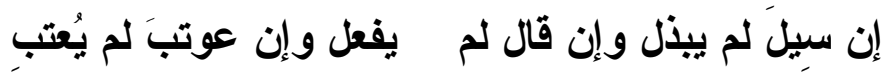

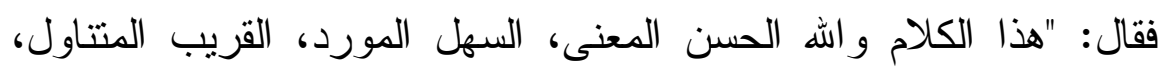

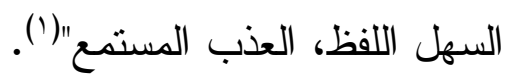

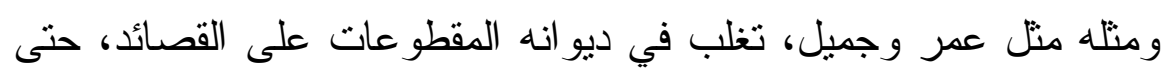
لنجد له أحيانا مقطو عات من بيتين فقط، منتل مقطو عته:

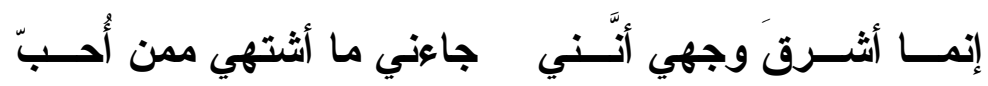

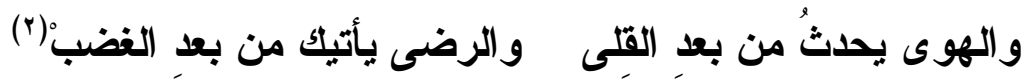

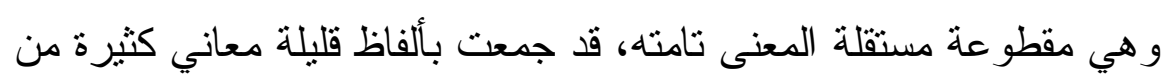

شؤون العاثق وأحواله، وتتجلى في مقطوعات العباس بن الأحنف عامة

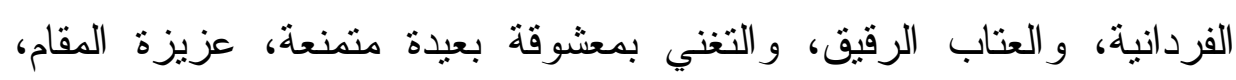

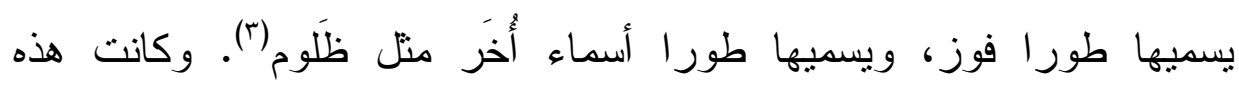

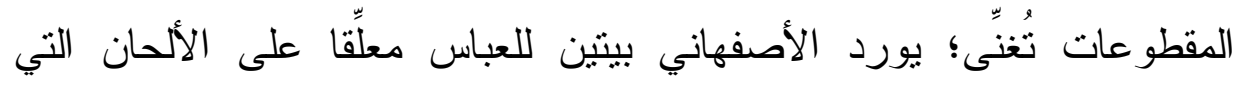

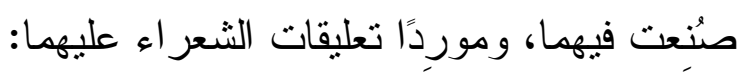

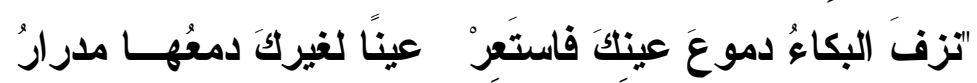

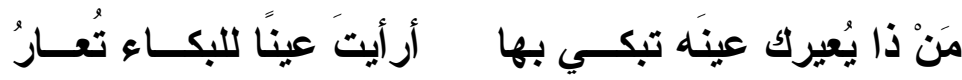

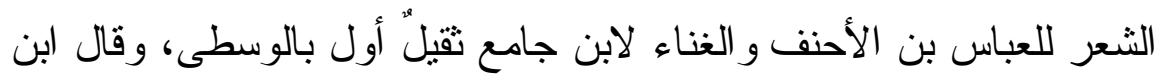

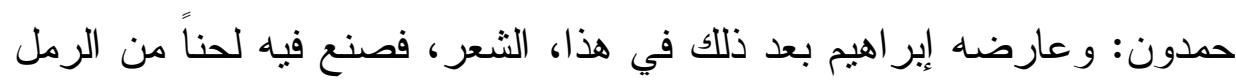

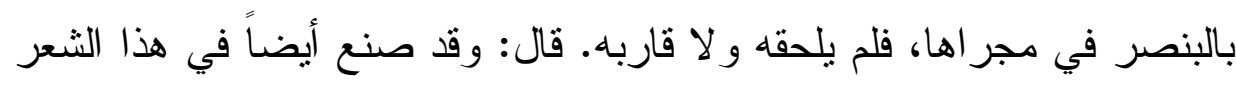

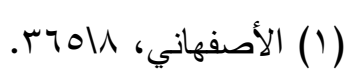

(r) العباس بن الأحنف، ديوان العباس بن الأحفف، ت: كرم البستاني (بيروت: دار صادر، 
لحن" خفيف فاسد الصنعة محدث ليس ينبغي أن يذكر هاهنا.حدثي

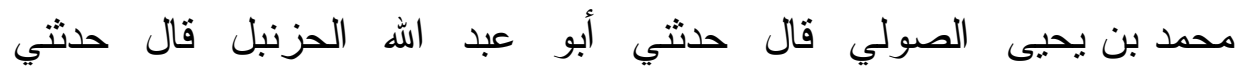

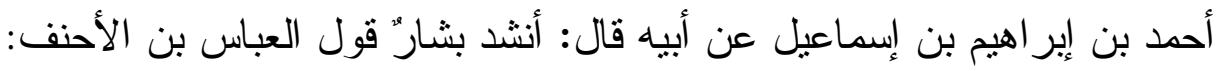

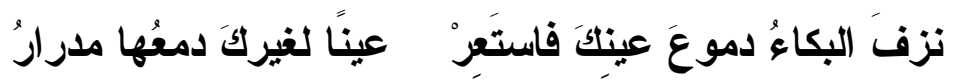

فقال بشار: لحق واله هذا الفتى بالمحسنين، وما زال يدخل نفسه معنا ونحن نخرجه حتى قال هذا الثعر ... ومما يغنى فيه من قصيدة العباس بن الأحنف الرائية التي هذا لهال الصوت الأخير منها قوله:

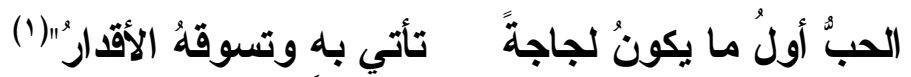

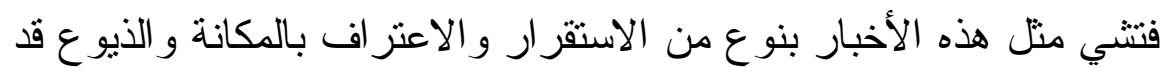

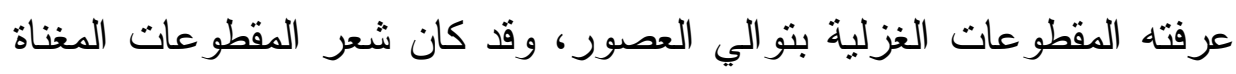

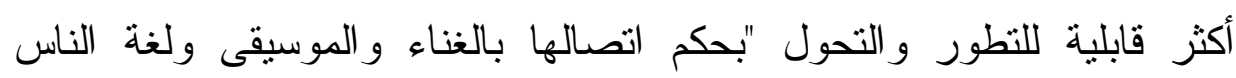

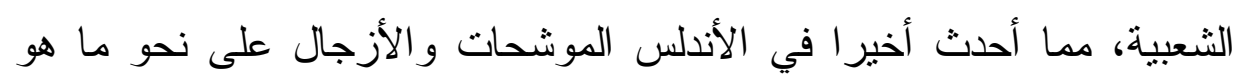

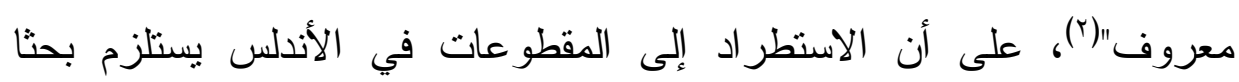

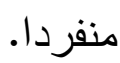

ونلاحظ على كثير من المقطوعات الغزلية افترانها بالقصص، فتأتي

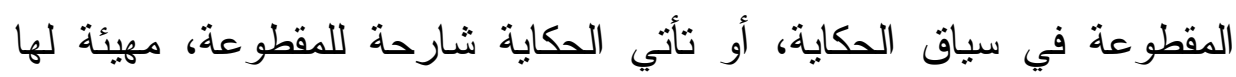

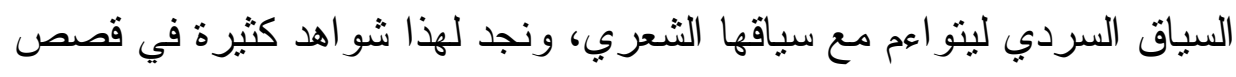

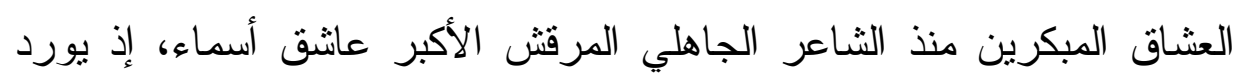
المفضل الضبي (ت. VA هـ) في المفضليات للمرقِّ الأكبر القطعة الثعرية 


\section{د. · جوخة الحارثي}

التي يقال إنه كتبها على رحل الرجل الذي غدر به في طريقة إلى دار حبييته

$$
\text { وتركه مريضا في كهف: }
$$

\section{يا صاحبيَّ تلوَّمَا لا تعجلا إن الرحيلَ رهينُ ألا تعــلا}

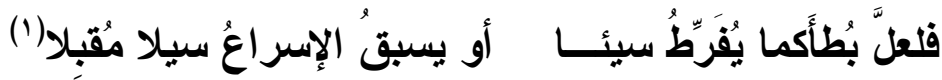

فالقطعة الشعرية تبرر هذا المشهد من حكاية المرقش الأكبر وتبسط تفاصيله، وتكون سببا في وصول إخوة المرقش إلى الرجل الغادر و الانتقام منه، بعد قراءة هذه الأبيات (وتمامها في المفضليات) على رحله. ففي منل هذه السياقات لا يمكن أن نفهم المقطوعات الشعرية بمعزل عن الحكايات المصاحبة لها، وهذا ما نجده متجليا فيما بعد في ظاهرة العشاق العذريين، في أواخر العصر الإسلامي وأوائل العصر الأموي، و أخبار هم المرتبطة بالمقطوعات الثعرية تملأ كتاب الأغاني(؟)، و ومن بعدهم العباس بن الأحنف، من العصر

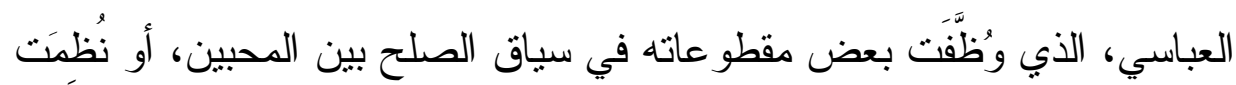

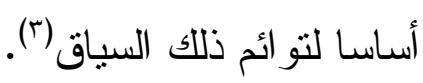

(1) المفضل بن محمد الضبي، المفضليات، ت: أحمد محمد شاكر وعبد السلام هارون

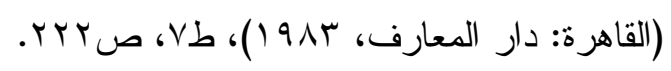

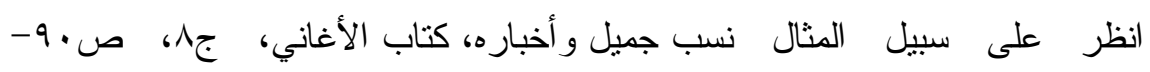

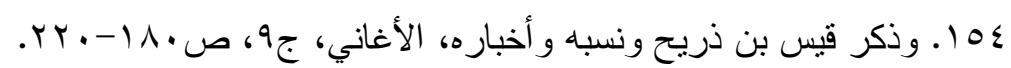

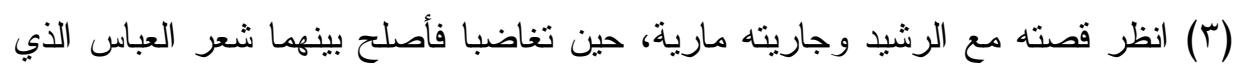

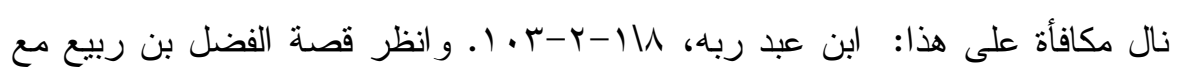
الجارية التي تأخرت عن استرضائه، فلم يجد مخرجا إلا في أبيات العباس:

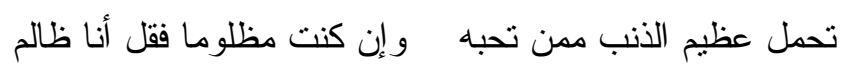
فإنك إلا تغفر الذنب في الهوى يفارقلك من تهوى و أنفك ر اغم

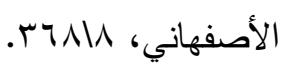


وبتو الي القرون التاريخية والأدبية، ارتبطت المقطوعات الغزلية ارتباطا

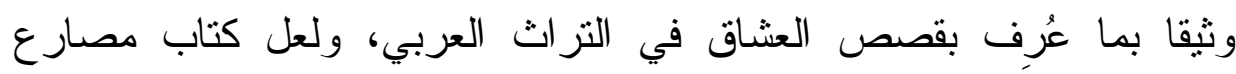

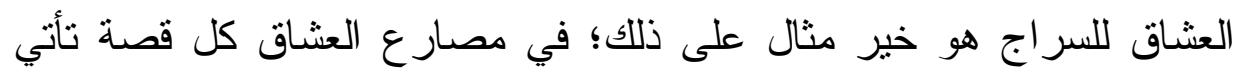

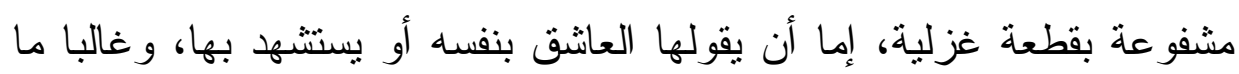

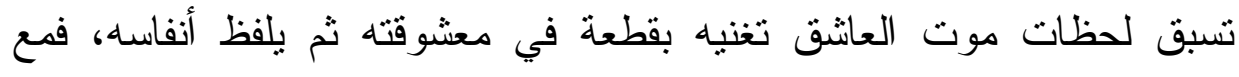

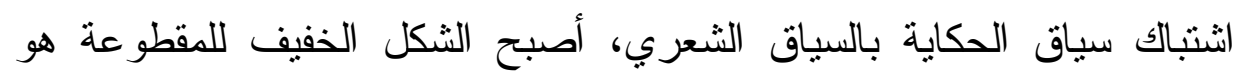
الثكل الأكثر نجاعة في توصيل فكرة كتب أخبار العشاق، حيث يشتبك الخبر

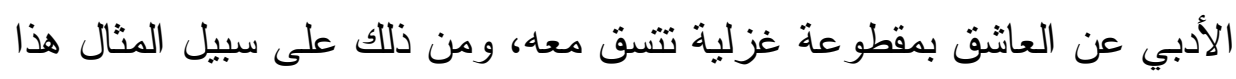
الخبر: "مررت بدير هرقل أنا وصديق لي، فقال لي: هل للك أن تدخل فترى من

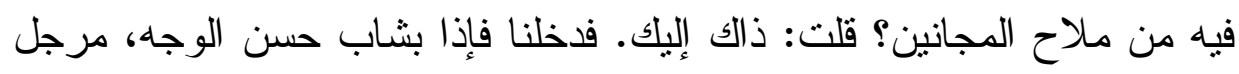

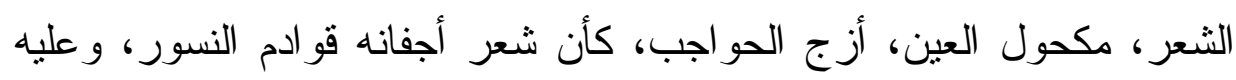

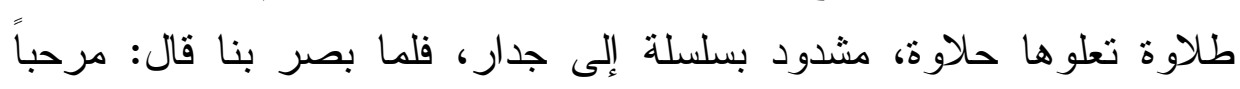

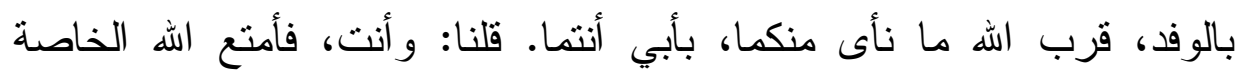

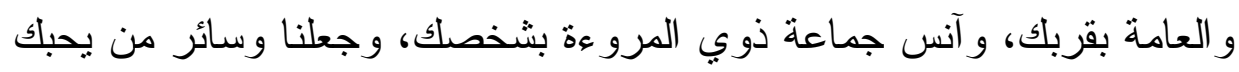
فداءك. فقال: أحسن الله عن جميل القول جز اءكما، وتولى عني مكافأتكما. قلنا: وما تصنع في هذا المكان الذي أنت لغيره أهل؟ فقال:

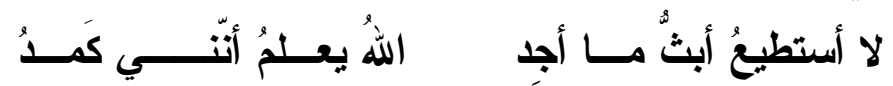

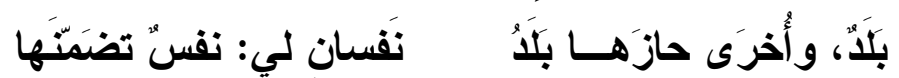

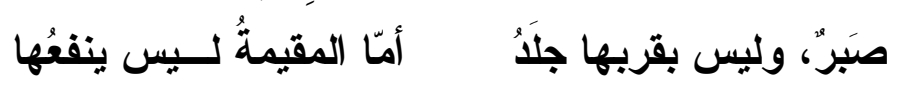

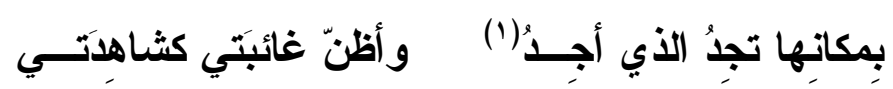

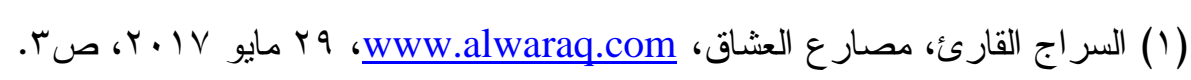


د · جوخة الحارثي

وينتهي الخبر بمقطوعة أخرى ينثدها العاثق المجنون، ثم ينتحر بالسلسلة

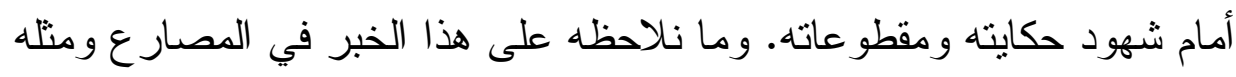

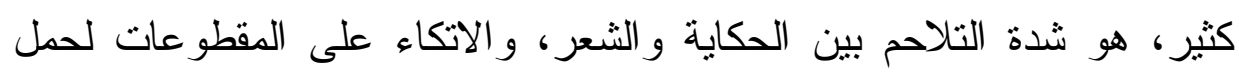
رسالة العشق، الذي لم يعد هنا غز لا عابثا و إنما كمد خالص أعقب انشطار

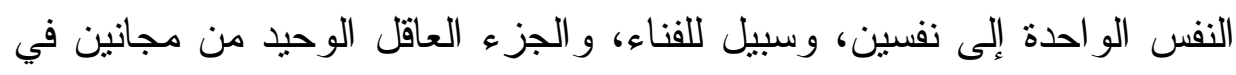

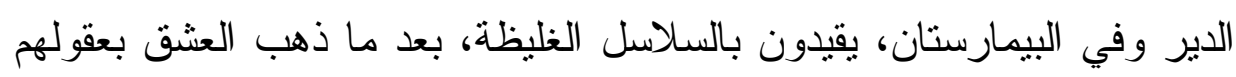

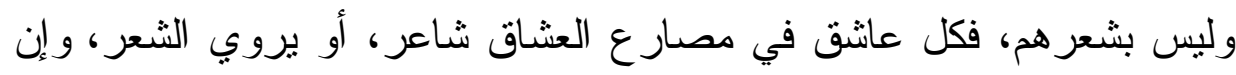

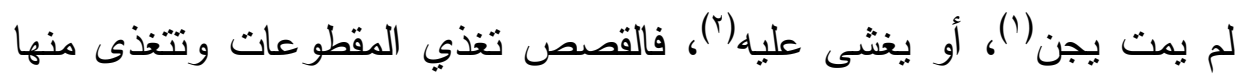
فهي علاقة تبادلية.

$$
\text { (1) (1) السابق، صه. }
$$


خاتمة:

نلاحظ مما سبق أن مصطلح "المقطوعة" قد ظهر منذ القرن الثالث

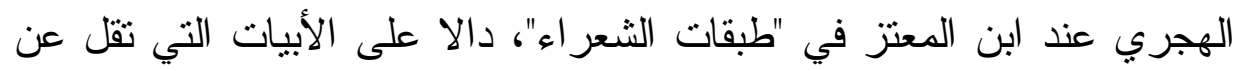

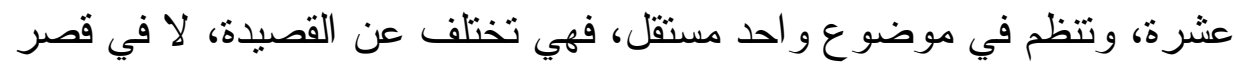

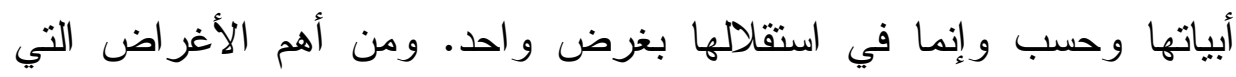

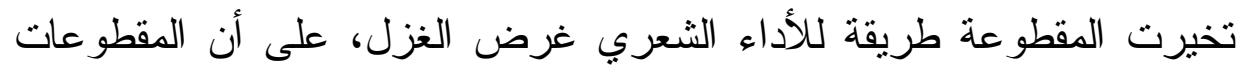

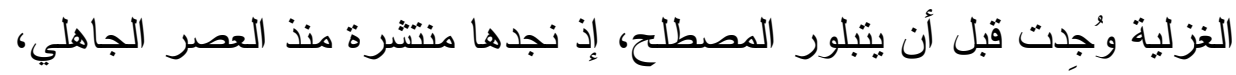

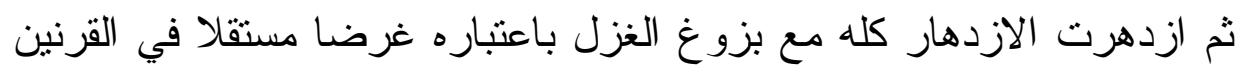

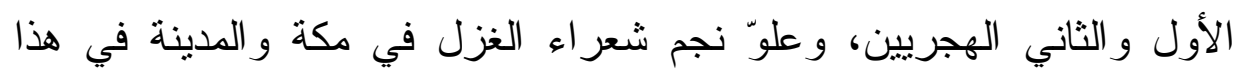

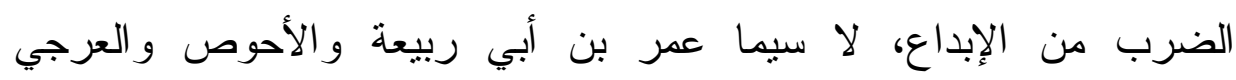

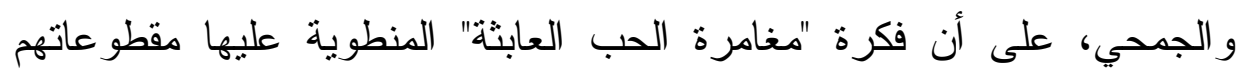

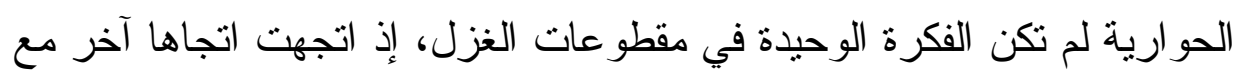

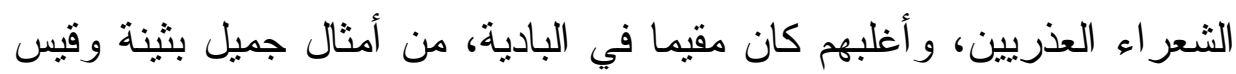

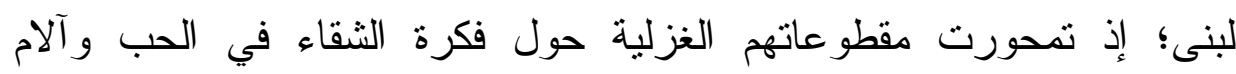

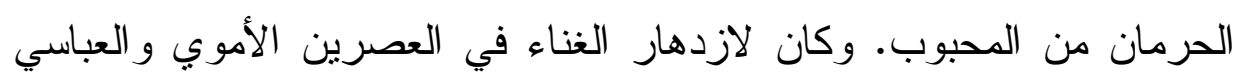
اليد الطولى في شيوع المقطو عات الغزلية وتلقي الناس المعجب بلان بها. وقد لاحظنا تجلي خصائص التجديد الثعري في المقطوعة أكثر منه في

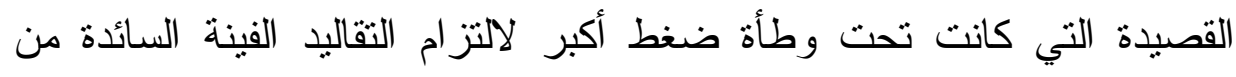
المقطوعة التي قد يكتبها الثاعر لإمتاع نفسه أو جمهوره أو للهزل أو للتنعبير

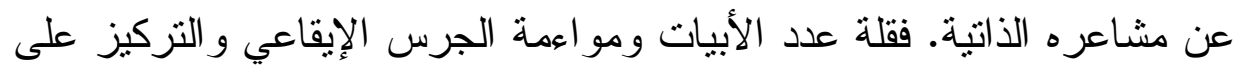

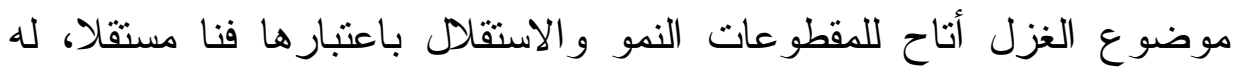

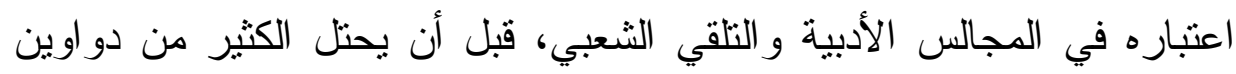

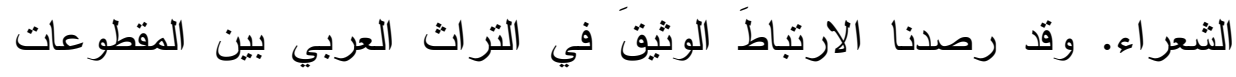




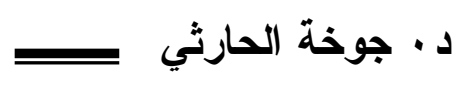

الثعرية الغزلية وقصص العشاق و المحبين، فالحكاية النثرية تفسر المقطوعة دوخه

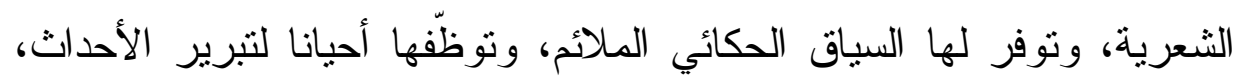

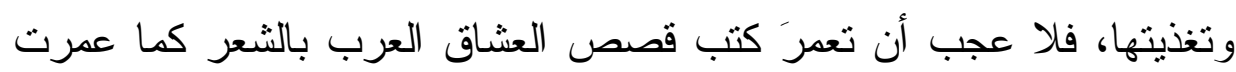
بالنثر ، فالعلاقة بين المقطو عات الثعرية و الحكايات العشقية علاقة تبادلية. * * 
-ابن رشيق القيرواني، العمدة في محاسن الثُعر و آدابه ونقده، ت: محمد محي

$$
\text { الدين عبدالحميد، طه (بيروت، دار الجيل، (919 (1)). }
$$

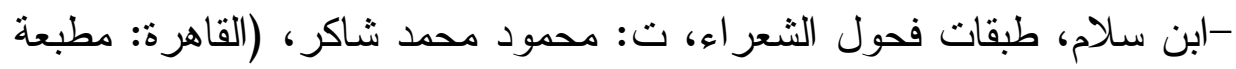

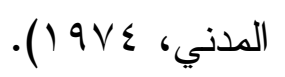

-ابن عبد ربه، العقد الفريد، ت: محمد سعيد العريان (القاهرة: مطبعة

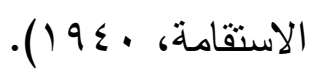

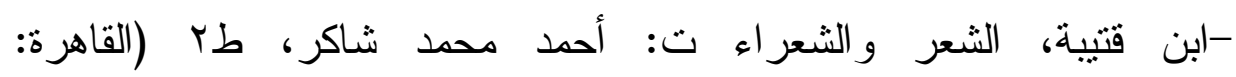

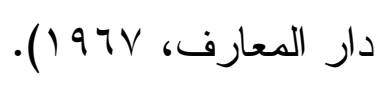

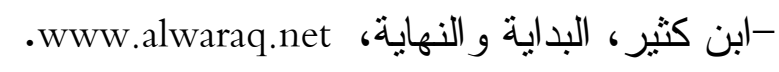
-ابن المعتز، طبقات الثعراء، ت: عبد النبة الستار أحمد فراج، طع (القاهرة:

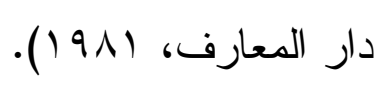

-أبو الحسن علي بن الحسن الباخرزي، دمية القصر وعصرة أهل العصر،

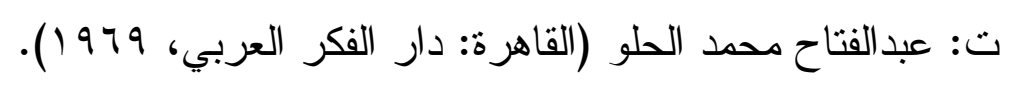

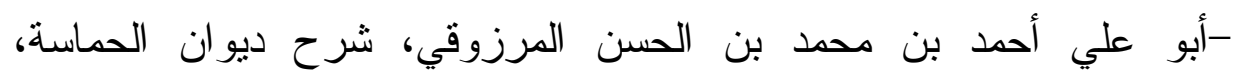
ت: أحمد أمين وعبد السلام هارون، جا (بيروت: دار الجيل، (99 (1)). - -إحسان عباس، شعر الخوارج، طץ (بيروت: دار الثقافة، ع و 1 ). -الأصفهاني، الأغاني، طب (بيروت: دار الفكر - دار مكتبة الحياة، 1907 (1).

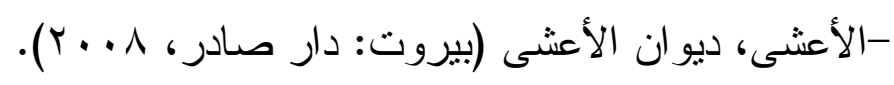

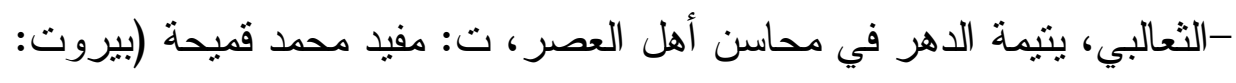

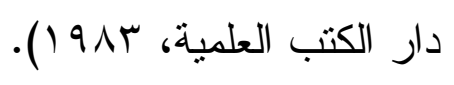

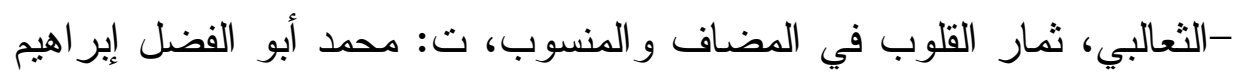

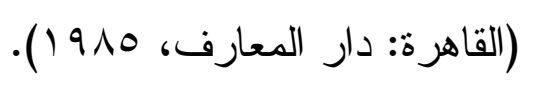




\section{د · · جوخة الحارثي}

-الجاحظ، الحيوان، ت: عبدالسلام هارون، ، طץ (القاهرة، مطبعة مصطفى دوحهي

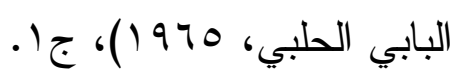

-جميل بثينة، ديو ان جميل بثينة، ت: فوزي عطوي، طب (بيروت: دار صعب، .$(191$.

-حسان بن ثابت، ديو ان حسان بن ثابت، ت: وليد عرفات (لندن: ستيفن أوستن

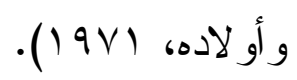

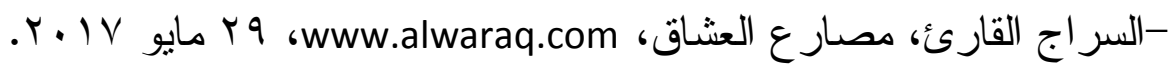
-شوقي ضيف، الثعر و الغناء في مدينة ومكة لعصر بني أمية، ط؛ (القاهرة:

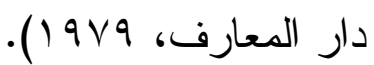

-الطبري، تاريخ الرسل والملوك، ت: محمد أبو الفضل إير اهيم (القاهرة: دار المعارف، ، - (199 ).

-العباس بن الأحنف، ديوان العباس بن الأحنف، ت: كرم البستاني (بيروت: دار صادر ، 9 (1) ).

-عبداله عبد الرحيم عسيلان، حماسة أبي تمام وشروحها دراسة وتحليل (القاهرة: دار إحياء الكتب العربية، 9 (1) ).

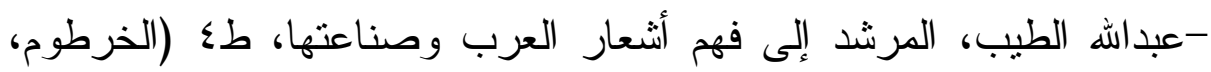

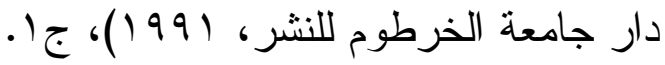
-عبد القادر البغدادي، خزانة الأدب، walw.alwaraq.net. -عبد الكريم النهشلي، المتع في صنعة الثعر، ت: محمد زغلول سلام (الإسكندرية، منشأة المعارف، . • (191). -عبد المنعم أحمد صالح، ديوان الحماسة لأبي تمام حبيب بن أوس الطبان الطائي برواية أبي منصور موهوب بن أحمد الجواليقي (بيروت: دار الجيل،

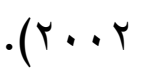

- عماد الدين الأصفهاني، خريدة القصر وجريدة العصر، www.alwaraq.net 
-عمر بن أبي ربيعة، ديوان عمر بن أبي ربيعة، ت: عبداله: الرحمن المصطاوي

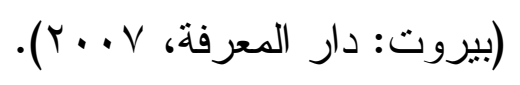

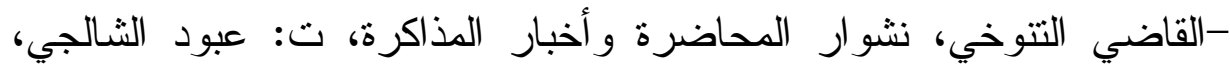

$$
\text { جr، طץ (بيروت: دار صادر ، } 1990 \text { (1). }
$$

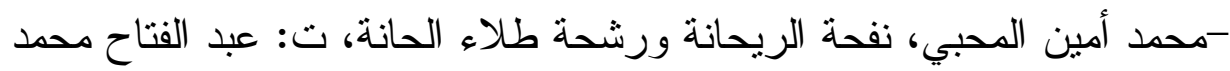

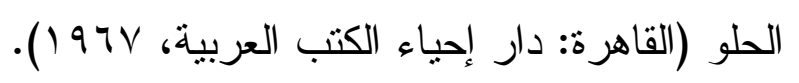

-محمد عباسة، اللهجات في الأزجال و الموشحات الأندلسية، إنسانيات: المجلة

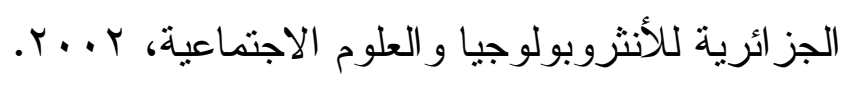

- المرزوقي، الأمالي، woww.alwaraq.net.

-المفضل بن محمد الضبي، المفضليات، ت: أحمد محمد شاكر وعبد السلام

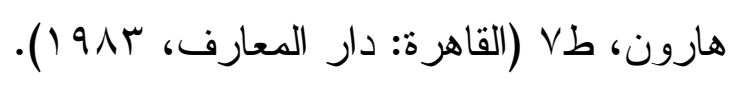

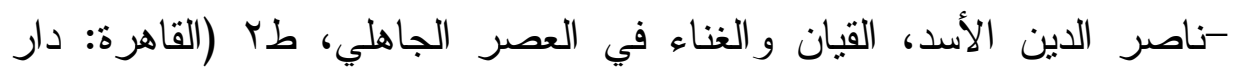

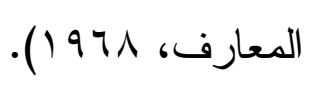

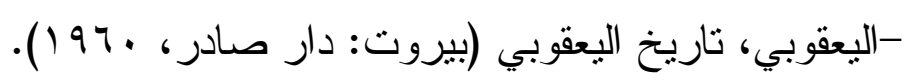

-Margoliouth, The Origins of Arabic Poetry, www.cambridge.org \core, on $r$ Novmber, $Y \cdot 17$.

-M. Badawi, "From Primary to Secondary Qasidas: Thoughts on the Development of Classical Arabic Poetry", Journal of Arabic Literature, $\operatorname{vol.11}(194 \cdot)$. 